This item was submitted to Loughborough's Institutional Repository (https://dspace.lboro.ac.uk/) by the author and is made available under the following Creative Commons Licence conditions.

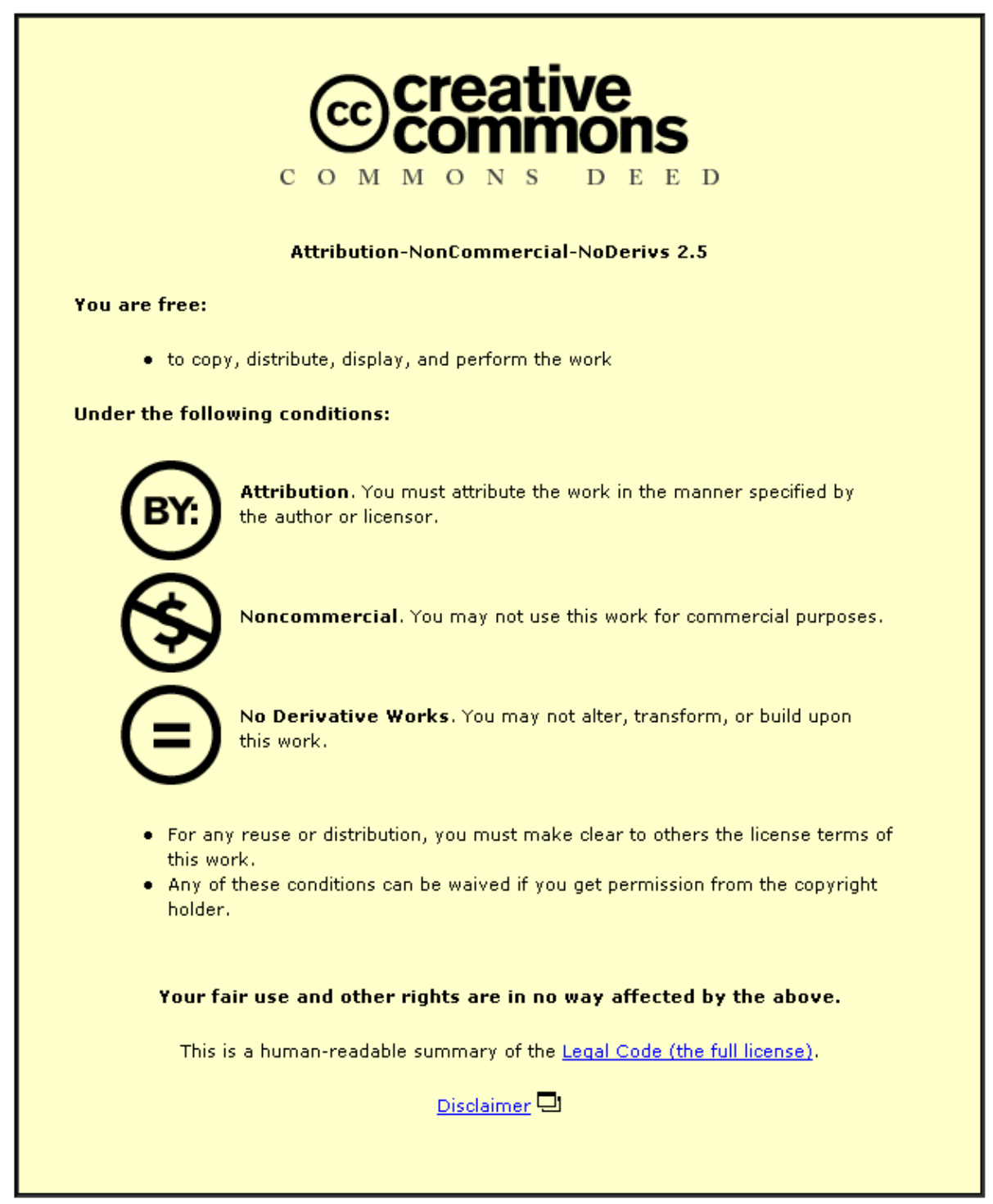

For the full text of this licence, please go to: http://creativecommons.org/licenses/by-nc-nd/2.5/ 
Pay Comparisons: An Analysis of UK University Vice Chancellors Pay Awards

\section{Heather Tarbert*}

\section{Kaihong Tee**}

And

Robert Watson***

*The Business School, Glasgow Caledonian University, Glasgow, UK

** Business School, University of Aberdeen, Aberdeen, UK

*** Durham Business School, University of Durham, Durham, DH1 3BL, UK

Address for correspondence: Robert Watson, Durham Business School, University of Durham, Durham, DH1 3BL, UK, E-mail: Robert.Watson@,Durham.ac.uk 
Pay Comparisons: An Analysis of UK University Vice Chancellors Pay Awards 


\title{
Pay Comparisons: An Analysis of UK University Vice Chancellors Pay Awards
}

\begin{abstract}
This paper examines UK University Vice Chancellors (VC) pay awards. The empirical analysis, covering the period 1997 to 2002, evaluates the impact upon VC pay awards of university performance measures, an internal pay comparison measure and two external pay comparisons, i.e., the pay of other VCs and the pay of CEOs leading comparable-sized UK firms. We find no evidence that VC pay awards are related to any of the performance measures, though the positive relationship found between changes in the proportion of other highly-paid employees and VC pay awards suggests that internal pay comparisons play an important role in remuneration committee decision making. Of the two external pay benchmarks, the pay received by other VCs has the largest positive impact upon VC pay awards. Nevertheless, the (much smaller) partial adjustment of VC pay explained by the difference between the two external pay benchmarks was also statistically significant. Thus, whilst average VC pay increased by some $40 \%$ over the period, this was significantly less than the increase in the pay of comparable UK CEOs. We suggest that this conservatism by university remuneration committees stems largely from political rather than financial constraints.
\end{abstract}

Key Words: CEO Pay, University Vice Chancellor's Pay, Pay Comparisons. 


\section{Pay Comparisons: An Analysis of UK University Vice Chancellor's Pay Awards}

\section{Introduction}

This paper examines the pay awards received by UK University chief executive officers, i.e., "Vice Chancellors" (VC) ${ }^{1}$, over the 6 year period from 1997 to 2002. Traditionally, VC pay has reflected internal university pay structures that shared many of the characteristics of public sector bureaucracies, i.e., an extreme "compression" of relative pay rates between grades and significantly lower salaries or incentives for top management than in the case of comparable profit-oriented organisations (Cragg and Dyck, 2000). In this context, VC pay awards were wholly uncontroversial as their pay levels were relatively low, with pay awards closely related to what was received by other University employees and those in comparable public sector positions. However, due to successive UK governments being unwilling to pay the full costs associated with their ambitious expansion policies over the past 20 or so years, universities have had to find ways of lowering their unit costs (e.g., by adopting less costly teaching methods) and/or of generating alternative income streams, primarily from research contracts and fees from postgraduates and non-UK/EU students. The increased competition for fee-paying students and research funds has impacted on internal pay structures as universities have had to compete for high quality academic faculty and to recruit new and often relatively highly paid, specialists (e.g., in finance or marketing) to identify and manage these new income streams. In this new competitive environment, internal university pay and incentive systems, particularly at those institutions most successful at attracting additional research and teaching income, have inevitably become more "tournament-like" and flexible to reflect external labour market conditions.

Though the opening up of internal pay structures has improved the pay of many managerial, professional and professorial grade employees, the most widely-reported consequence of this process is the fact that VC pay has risen at a consistently faster rate than the pay of most other University employees. Indeed, VC pay awards have become highly controversial. As can be seen from Figure 1, which documents the reporting of and reactions to VC pay awards each year from 1995 to 2003 published in the Times Higher Educational Supplement (THES), the THES Leader and editorials and the reactions from Union spokespersons, the annual publication of VC pay details now invariably produces highly critical comments (e.g., "outrageous", "shameless") from academic Union officials unable to negotiate similar percentage pay awards for their members. Nevertheless, as is apparent from many of the comments in Figure 1, VC's remain relatively 
poorly paid compared with comparable professionals or the CEOs of similar-sized UK organisations. For example, the highest paid VC in 1995, Derek Roberts of University College London, who had formally been a director of GEC, claimed that "his pay had fallen by a factor of 3 when he moved to UCL."

We argue that university remuneration committees, particularly now that increasing numbers of new VCs are being appointed from outside the university sector, necessarily have to base VC pay awards upon some combination of internal and external labour market pay comparisons. Even so, despite the fact that average VC pay levels - and to a lesser extent the pay of other senior staff - have risen significantly, we argue that political factors, primarily academic labour union complaints about VC pay rises, rather than financial constraints have inhibited remuneration committees from raising VC pay anywhere close to the levels typically received by the CEOs running comparable- sized UK companies.

The paper is structured as follows. In section two, we discuss the pay setting process, in particular the role of remuneration committees, and the empirical findings relating to CEO pay awards in the UK. The financial and governance issues currently confronting UK Universities, and the system by which VC and other senior staff pay is determined are discussed in section 3 . The empirical hypotheses, empirical models, data and variables used to evaluate the determinants of VC pay awards are presented in section 4. The empirical results, which focus on VC pay changes and include analyses relating to both the full sample and the pre-1992 and post-1992 University sub-samples, are presented and discussed in section 5. The final section examines the implications of our findings for the UK University sector and for the broader and continuing debates concerning the effectiveness of remuneration committees in controlling executive compensation.

\section{Remuneration Committees and CEO Pay in the UK}

There has been much media and public interest in the apparently "excessive" and "unjustified" pay increases enjoyed by senior executives in both the US and the UK over the past 15 years or so. The notions of "excessive" or "unjustified" pay awards are, of course, highly value laden and in much media reporting appear to be synonymous with CEO's and other senior executives receiving high pay awards relative to either (1) other employees and/or (2) irrespective of any obvious improvements in the performance of their organisations. Certainly, the average pay of 
senior executives, particularly the CEO, in the US and UK has increased at a much faster rate than that of other employees (Conyon and Murphy, 2000) and many empirical studies have failed to produce convincing evidence that $\mathrm{CEO}$ pay increases have been related to improvements in firm performance (Barkama and Gomez-Mejia, 1998). For example, many published studies have tested CEO pay change models of the following form:

$$
\mathrm{LnW}_{\mathrm{it}+1}-\mathrm{LnW}_{\mathrm{it}}=\alpha+\Sigma \beta(\text { Performance })_{\text {it }}+\mathrm{u}_{\mathrm{it}}
$$

where:

$\mathrm{LnW}_{\mathrm{it}+1}-\mathrm{LnW}_{\mathrm{it}}=$ the $\log$ change in CEO pay between time $\mathrm{t}$ and $\mathrm{t}+1$,

$\alpha=$ the estimated constant term which represents the average proportionate change in CEO pay between time $\mathrm{t}$ and $\mathrm{t}+1$ when $\Sigma \beta(\text { Performance) })_{\text {it }}=0$, $\Sigma \beta(\text { Performance })_{i t}=$ a vector of one or more firm performance indicators and their respective estimated $\beta$ coefficients observed at time $\mathrm{t}$ and, $\mathrm{u}_{\mathrm{it}}=$ the estimated residuals representing the unexplained variance in CEO pay changes.

As Conyon, et al (1995) have argued, the majority of reported empirical estimates of equation (1) have tended to indicate that such models have relatively low explanatory power and typically result in highly significant positive estimated $\alpha$ 's and small and/or insignificant $\beta$ coefficient(s) irrespective of either the firm performance measure(s) used or the definition of CEO pay being tested.

Some academics have attributed these results to managerial power, or simply greed. Bebchuk and Fried (2003), for example, contend that managerial entrenchment and poor independent director monitoring and control are endemic in the US due to its explicitly manager-friendly corporate laws and limited shareholder rights. To these authors, managerial entrenchment and control over the board of directors, coupled with diversified (and hence largely acquiescent) shareholders, are the primarily factors responsible for recent hikes in executive pay because they allow managers to effectively determine their own pay. Bebchuk and Fried (2003) argue that the only constraints upon pay are disclosure rules that make it more difficult to disguise and/or avoid reporting the real costs to shareholders and the increased risk of provoking shareholder revolts and public "outrage". 
The managerial power framework is useful in focusing attention on the ever-present possibility that entrenched executives may be able to extract substantial economic rents from their positions. However, this framework does not fit well with the observation that when CEOs move firms, i.e., when by definition they are not entrenched, they appear to experience few difficulties in being able to negotiate even more generous pay packages for themselves than they had with their previous employer. Also, managerial power does not appear to provide a convincing explanation as to why CEO pay has increased in similar ways throughout the developed world irrespective of the significant differences between countries in terms of managerial entrenchment and the presence of alternative corporate governance control mechanisms. For example, UK corporate law and governance, though similar to the US in terms of legal origins (English common law), disclosure and financial reporting, unitary boards, remuneration committees and an apparently identical shareholder focus, provides much more extensive shareholder voting rights and powers to control and dismiss the board of directors. These stronger shareholder rights, along with higher levels of institutional ownership and fewer constraints on the market for corporate control, have not produced significant managerial entrenchment problems for the UK. Even so, the UK has experienced much the same pattern of rapidly rising CEO pay unrelated to firm performance improvements as has the US (Conyon and Murphy, 2000).

Many financial economists (for a review, see Conyon, 2006) have taken the more plausible view that the general increase in executive pay reflects changes in the price firms are willing to pay for scarce executive and other specialist human capital. It has frequently been argued that firms have been willing to pay senior executives more due to the increasing size, complexity and profit making opportunities of firms. The theoretical literature suggests that greater competition for scarce human capital will generate internal promotion and pay outcomes that have all the attributes of competitive “tournaments” (e.g., Lazear, 1989, Lazear and Rosen, 1981; Martin, 2001; O'Reilley, et al, 1988). Tournaments necessarily produce much more diverse pay outcomes as the value of the winner's "trophy" (the wage increase from the promotion and the opportunity to progress to the next hierarchical level) increases disproportionately in order to motivate the requisite degree of competition for key positions within the organisation. Another implication of tournament theory is that greater competition and higher rewards lower down the organisational hierarchy will necessarily lead to proportionately larger pay increases for more senior organisational members. 
In both the US and UK, remuneration committees, consisting of part time, non-executive directors that meet on average only twice per year, have long been the institutional mechanism by which these internal and external labour market pressures have been translated into senior executive pay awards (for a review, see Stiles and Taylor, 2000). In the UK, every corporate governance code from Cadbury (1992) to the current "Combined Code" (2002) has recommended that remuneration committees take account of labour market pressures by basing pay awards primarily upon what "comparable" companies were paying their executives and, for incentive alignment purposes, to make pay more closely related to improvements in firm performance ${ }^{2}$. In practice, this encouragement of remuneration committees to focus on pay comparisons and performance related pay has tended to increase CEO pay levels as risk averse and resource constrained remuneration committees have sought to avoid being perceived as under-valuing their senior executives. The evidence suggests that remuneration committees have realised that they can minimise the possibility of boardroom conflict, recruitment and retention problems and inadvertently signalling low managerial quality to outsiders, simply by paying their CEO somewhat more than the apparent market rate. Though, from the perspective of each individual remuneration committee, being relatively generous to the CEO is a reasonable strategy, the statistical impossibility for all CEOs to be paid more than average implies that their average pay levels will necessarily be "bid-up" over time. ${ }^{3}$

Remuneration committees' apparent “bidding-up" of executive pay has not, however, gone unnoticed by the business world. For example, the Institute of Directors (1995:4) felt obliged to advise its members that remuneration committees "should avoid setting packages which are generous in relation to market levels and beware of pressure always to be in the "upper quartile"'. In a similar fashion, the Combined Code has also highlighted this same problem:

"B.1.2 Remuneration committees should judge where to position their company relative to other companies. They should be aware what comparable companies are paying and should take account of relative performance. But they should use such comparisons with caution, in view of the risk that they can result in an upward ratchet of remuneration levels with no corresponding improvement in performance...."

It will be noted that though they were both able to recognise the tendency for remuneration committees to raise pay levels, neither the Institute of Directors nor the drafters of the Combined Code felt able to offer any suggestions as to how to reduce the problem.

A recent study by Ogden and Watson (2004), which focused on the UK water industry, has indicated that external political-stakeholder pressure can substantially limit the willingness of 
remuneration committees to ratchet up CEO pay. When they were privatized in 1989, the water companies had to rapidly transform themselves from public sector monopoly suppliers into market driven enterprises capable of earning a reasonable rate of return to their shareholders from their portfolio of regulated activities and non-regulated post-privatisation investments. This transformation from public sector bureaucracies into publicly listed enterprises ought to have led to the rapid adoption of pay levels and practices similar to other listed companies (see Cragg and Dyck, 2000). ${ }^{4}$ Nevertheless, throughout the early 1990's, the water companies were subject to much public criticism arising from increased charges (due largely to the costs associated with new regulatory standards) and a widespread, but demonstrably false, belief that their CEOs were grossly overpaid and that excessive executive pay was responsible for the increased charges to customers. $^{5}$ Despite good post-privatisation corporate performance, subsequent to these widely reported public criticisms, the pay of the water company CEOs rose only modestly in comparison to the pay increases received by other UK CEOs.

Interviews with remuneration committee chairmen reported in Ogden and Watson (2004) confirmed that the intense media and political scrutiny of the remuneration committee's decisions had not merely inhibited increases in CEO salaries but, in 1995 after being criticised by the Greenbury Report (1995), had resulted in all the water companies abandoning their recently introduced executive share option programmes. The interviewees reported that these episodes had made them very concerned with ensuring that they could "justify" their pay decisions to outsider stakeholders and that they had the support of major shareholders prior to making any major pay decisions. This circumspection brought about by political pressures clearly constrained water company CEO pay awards but, as the committee chairmen were anxious to point out, the constraints on pay were causing recruitment and retention problems and the extensive "legitimation" exercise also consumed significant corporate resources. For example, the water company remuneration committees typically had 8 meetings per year, which is some 4 times the average number of meetings per annum that other UK companies have (Conyon, et al, 2000). Clearly though, in the absence of strong regulatory and/or political pressure, most remuneration committees have had neither the resources nor any incentives to risk paying their executives significantly less than the pay received by comparable executives employed elsewhere. 


\section{UK University Governance and Vice Chancellor's Pay}

Though UK universities are still often thought of as quasi-public sector organisations, over recent years they have acquired many of the characteristics, cash flow risks and pay practices of commercial enterprises. Indeed, UK Universities are legally independent, Charitable (i.e., nonprofit making) institutions; that is, they are not owned by the State, their debts are not guaranteed by any public body, their employees are not public servants, no government representatives sit on their governing councils and each institution is free to pursue their own student and staff recruitment policies, research missions and other investment strategies. UK Universities operate in accordance with their own voluntary code of governance, published by the "Committee of University Chairmen" (CUC, 2002, 2004). The governing bodies of UK Universities, the "University Council", , performs all the same functions as the "board of directors" of commercial corporations:

" 3.2 The council is the executive governing body of the university. It is responsible for the university's finances and investments and for the management of the university estate and buildings... subject to the powers of the senate in academic matters, the council has responsibility for the conduct of all the affairs of the university." (CUC 2002, p. 11).

University Councils are expected to meet between 3 and 6 times per year and in 2001 had an average membership of 33 (CUC, 2002, p 11). Not surprisingly given the many distinct constituencies represented on the councils, this is more than twice the average size of the boards of directors of comparable UK companies. Just as UK company boards are required by the Combined Code to have an independent Chairman and a majority of independent directors, so too are University Councils:

"3.3 It is an important principle that the council has a lay majority, that is a majority of members who are not staff or students of the university. Its membership ... will typically include officers of the university, both lay and academic, members appointed by the court, members appointed by the senate, co-opted members, local authority representatives, elected staff members and student representatives .... (p. 11).

The CUC code also unambiguously describes the VC as "the chief executive of the university" with "overall responsibility for the executive management of the institution and for its day-to-day direction, and is accountable to the council (and in some universities to the senate) for the exercise of these responsibilities" (CUC, 2002, p13). The process by which VC and other senior staff pay awards are determined is, to all intents and purposes, identical to that obtaining in the private sector: 
"4.43 Governing bodies should establish a remuneration committee to determine and review the salaries, terms and conditions (and, where appropriate, severance payments) of the head of the institution and such other members of staff as the governing body deems appropriate. A minimum membership of such a committee should be the chairman of the governing body and at least three other lay/independent members, including the lay treasurer if such an office exists. The head of the institution should also be a member of the committee for all salaries except his/her own. Any member of staff should withdraw from the committee when his/her own salary, terms and conditions or severance payments are under consideration.

4.44 The remuneration committee should seek comparative information on salaries and other benefits and conditions of service in the higher education sector. Two sources of information are available: the CUC has a database of salaries, benefits and conditions of service for heads of institution (currently available only to chairmen of governing bodies); and the Universities and Colleges Employers' Association (UCEA) collects data on the salaries of other highlygraded staff.

4.45 When considering severance arrangements for senior staff, the remuneration committee must represent the public interest and avoid any inappropriate use of public funds. The committee should be careful not to agree to a severance package which staff, students and the public might deem excessive. Contracts of employment for senior staff should specify periods of notice of not more than 12 months, and should not provide for pension enhancements." (CUC, 2002, p 26)

Thus, the VC's pay is determined by a remuneration committee made up of independent "outsiders" (prominent local and national figures in business, politics, professional associations and the arts and media) drawn from the membership of each university's governing Council. As can be seen from the above extract, apart from the warning "not to agree to a severance package which staff, students and the public might deem excessive", the CUC code does not offer remuneration committees any guidance as to the criteria they ought to employ in determining an appropriate and acceptable level of VC pay. The committee members are, however, supplied with comparative pay information regarding what other UK VC's and other highly paid university staff earn. They also have ready access to a third source of comparative pay information because prior to deciding the VC's pay, the remuneration committee will typically have made pay awards in respect of all the professors and other senior staff and in their institution.

The remuneration committee will also have a fourth potential source of relevant comparative pay information available to them, either from pay consultants or from personal experience from being an executive or board member elsewhere; namely the pay received by other UK CEOs. The pay received by CEOs ought to be a relevant benchmark for remuneration committees since the CUC code describes the post of VC as the highest executive position in a UK university, with 
much the same leadership, financial, operational and strategic responsibilities as the CEOs of conventional business organisations. Whilst a minority of universities, predominantly "post1992" institutions that were granted independence and University status only in (or, in a few cases, after)1992, still obtain the majority of their income from regulated UK and EU undergraduate numbers and fees, many of the high status pre-1992 institutions have successfully pursued strategies that have significantly reduced their dependence upon State-funding. Though the pre-1992 institutions typically still receive significant sums of public money for core research from performing well in terms of the peer-review driven RAE, much of their income now comes from non-public sources such as commercial sponsors of research and other services and the recruitment of significant numbers of (non-EU) undergraduates and postgraduate students willing to pay realistic market course fees.

As can be seen from the descriptive statistics presented in Table 1, there was already a high degree of diversity between institutions in terms of research income, the composition of the student intake and internal wage structures in 1997. Over the subsequent 5 years to 2002, it can also been seen that this diversity increased as universities with already high academic reputations (the pre-1992 group) have tended to be more successful at generating additional research and fee income. As universities have become ever more exposed to national and international competition for students, research funds and high quality research and professional staff, it seems unlikely that their remuneration committees will view the VC's job as being any less difficult or complex than the jobs of CEOs running similar sized commercial enterprises.

In financial terms, it is not obvious from the descriptive statistics presented in Table 1 why VC pay has become a contentious issue. Average University income was almost $£ 124$ million in 2002, having increased by slightly more than 30\% between 1997 and 2002, whilst average VC pay was almost $£ 140,000$ in 2002 , having increased by $39 \%$ over the same period. The average increase in VC pay over the five years of approximately $£ 40,000$ is quite trivial and accounts for a mere $1.33 \%$ of the $£ 30$ million increase in University income over the same period. Both the level of VC pay in $2002(£ 139,500)$ and the $£ 40,000$ average increase are also very low when compared to the $£ 403,400$ average pay of the Datastream UK CEOs in 2002 and their $£ 120,000$ average increase in pay over the same period. Indeed, VC pay levels seem particularly low in comparison to our estimate of what they ought to be paid on the basis of the Datastream pay level Model parameters. ${ }^{7}$ On this basis, average VC pay in 2002 ought to be more than $£ 200,000$ higher at $£ 342,700$, having risen by some $£ 140,000$ over the previous five years to reflect 
increases in total income and the pay received by other UK CEOs. Moreover, it is clear from the figures in Table 1, which detail the large percentage increases in the number of staff, particularly in the pre-1992 Universities that have earnings in excess of $£ 50,000$ and $£ 100,000$, that internal pay systems have been made much more responsive to external labour market pressures and that, as a consequence, $\mathrm{VCs}$ have not been alone in receiving relatively large pay rises over recent years.

Whilst it ought to be obvious from the figures involved that the extra $£ 40,000$ typically paid to VCs will have had no discernable negative impact on University finances or the ability or willingness of an institution to award pay increases to other employees, the academic staff trade unions have been highly critical of these fairly modest rises in VC pay. The percentage increase in average $\mathrm{VC}$ pay is, of course, significantly higher than the $16.3 \%$ average increase in the nationally negotiated pay awards to academic and academic-related staff below the grade of professor over the same 5 year period. ${ }^{8}$ Remuneration committees have no involvement in these nationally negotiated pay settlements. The academic labour unions, who have always insisted upon national bargaining, negotiate directly with the Universities and Colleges Employers' Association (UCEA). An obvious corollary of these national pay bargaining arrangements is that pay settlements are necessarily constrained by the parsimony of State funding and what the poorest institutions can "afford to pay". What ought to be equally obvious is that these financial constraints are irrelevant to remuneration committees when considering the VC's pay. As can be seen from Figure 1, the academic trade unions have consistently focused attention on the apparent "unfairness" of the disparity between VC pay awards and the typically much smaller awards to their members. Perhaps not surprisingly, Figure 1 also shows that the relatively few comments published in the THES from VCs or spokespersons of their collective lobby group (CVCP/UUK) have been largely restricted to drawing comparisons with the pay received by CEOs of similarsized firms and/or market competition to get the best staff.

\section{Hypotheses and Empirical Modelling of VC Pay Awards ${ }^{9}$}

In this section we present our hypotheses and describe the empirical methods used to model and test our hypotheses relating to UK VC pay awards. From the reviews of the process by which remuneration committees determine $\mathrm{CEO}$ and VC pay, it is evident that motivational, retention and signalling concerns have a pronounced tendency to ratchet up pay because, in the absence of binding financial or political constraints and/or poor corporate performance, remuneration 
committees will tend to play safe and award their CEO's pay increases that are generous relative to the external firm size/pay comparisons.

Particularly in institutions that derive a large proportion of their income from commercial activities, remuneration committees can be expected to view the salaries received by the CEOs of similar sized UK firms as being the most appropriate benchmark for determining their VC's pay. However, due primarily to perceived political (rather than financial) constraints, university remuneration committees are expected to demonstrate some caution and only partially adjust their VC's pay towards the external CEO pay benchmark.

Given the above, we evaluate the following five hypotheses in relation to UK University VC pay awards:

H1: Remuneration committees will reward VCs for improvements in University performance and, therefore, VC pay awards will be a function of observable changes in the size and composition of each University's total income and student numbers.

H2: Remuneration committees that have awarded high pay to other senior University staff will want to increase their VCs pay to maintain internal pay hierarchies and therefore VC pay awards will be positively related to the increase in the proportion of other high paid University colleagues.

H3: Remuneration committees will attempt to align their VC pay with the pay received by the VCs of similar-sized UK Universities and therefore VC pay awards will be influenced by observable deviations of their pay from an external (to the University) VC pay benchmark.

H3a: When Remuneration committees perceive that the pay of their VC is lower than the external (to the University) VC pay benchmark, they will make a larger adjustment towards this VC pay benchmark than when the VC appears to be overpaid relative to this VC pay benchmark.

H4: Remuneration committees will view the pay received by the CEOs of similar-sized UK companies as being an appropriate pay level for their VC but, due to perceived political constraints, will be prepared to only partially adjust VC pay to this higher level in any one year. Hence, empirically, VC pay awards will be characterised by a partial adjustment related to their 
perceived underpayment relative to an observable external (to the University sector) CEO pay benchmark.

H5: Remuneration committees will view the pay received by the CEOs of similar-sized UK companies as being an appropriate pay level for their VC but, due to political constraints, will adjust VC pay more readily to deviations from the external VC pay benchmark than to deviations in VC pay from the (higher) CEO pay benchmark. Hence, empirically, VC pay awards will be characterised by a positive partial adjustment to deviations from the external VC pay benchmark (as for H3), plus a much smaller positive adjustment of VC pay to the remaining deviation of VC pay from the CEO pay benchmark.

The empirical evaluation of the above hypotheses utilises a number of pay change models. To evaluate $\mathrm{H} 1$ and $\mathrm{H} 2$, we use an augmented version of equation (1) as follows:

$\mathrm{LnW}_{\mathrm{it}+1}-\mathrm{LnW}_{\mathrm{it}}=\alpha+\beta \operatorname{Ln} \Delta($ Incomeit $)+\beta \operatorname{Ln} \Delta($ Total Studentsit $)+\beta \operatorname{Ln} \Delta($ PG Studentsit $)+$ $\beta \operatorname{Ln} \Delta($ Overseas Studentsit $)+\beta \operatorname{Ln} \Delta($ Research Incomeit $)+\beta \operatorname{Ln} \Delta($ Staff $>£ 50 k i t)+u_{i t}+1$

Where:

$\mathrm{LnW}_{\mathrm{it}+1}-\mathrm{LnW}_{\mathrm{it}}=$ the (natural) log change in $\mathrm{VC}$ total pay between time $\mathrm{t}$ and $\mathrm{t}+1$, $\operatorname{Ln} \Delta($ Income it $)=$ the (natural) log change in University Income (Sales) between time $\mathrm{t}-1$ and $\mathrm{t}$, $\operatorname{Ln} \Delta$ (Total Studentsit) = the (natural) log change in student enrolments between time $\mathrm{t}-1$ and $\mathrm{t}$, $\operatorname{Ln} \Delta(\mathrm{PG}$ Studentsit $)=$ the (natural) log change in postgraduate student enrolments between time $\mathrm{t}-1$ and $\mathrm{t}$,

$\mathrm{Ln} \Delta($ Overseas Studentsit $)=$ the (natural) log change in overseas (non-UK/EU) student enrolments between time t- 1 and $\mathrm{t}$, $\operatorname{Ln} \Delta($ Research Incomeit $)=$ the (natural) log change in research income between time $\mathrm{t}-1$ and $\mathrm{t}$, $\operatorname{Ln} \Delta($ Staff $>£ 50 \mathrm{kit})=$ the (natural) log change in the number of University staff earning more than $£ 50,000$ between time $\mathrm{t}-1$ and $\mathrm{t}$, $\mathrm{u}_{\mathrm{it}+1}=$ the regression residuals.

We refer to this pay change model, which includes only internal (to the University) explanatory variables, as "Model 2". Estimated coefficients that are both positive and significant on one or more of the five performance measures would be evidence consistent with $\mathrm{H} 1$. A positive and 
statistically significant coefficient on the $\operatorname{Ln} \Delta(\operatorname{Staff}>£ 50 \mathrm{kit})$ variable would provide evidence consistent with $\mathrm{H} 2$.

In order to test hypotheses $\mathrm{H} 3$ and $\mathrm{H} 3 \mathrm{a}$, the impact of the external $\mathrm{VC}$ pay benchmark upon $\mathrm{VC}$ pay awards, we augment Model 2 with the following two variables:

$\mathrm{LnW}_{\mathrm{it}+1}-\mathrm{LnW}_{\mathrm{it}}=\operatorname{Model} 2+\beta\left(\mathrm{LnW}^{\mathrm{VC}} \mathrm{it}_{-} \mathrm{LnW}_{\mathrm{it}}\right)+\beta\left(\mathrm{LnW}^{\mathrm{VC}}{ }_{\mathrm{it}}-\mathrm{LnW}_{\mathrm{it}}>0\right)$

Where:

$\left(\mathrm{LnW}^{\mathrm{VC}}{ }_{i t}-\mathrm{LnW}_{\mathrm{it}}\right)=$ the difference between the estimated (natural) $\log \mathrm{VC}$ pay benchmark at time $\mathrm{t}$ and the (natural) log of the VC's actual pay at time $\mathrm{t}$.

$\left(\mathrm{LnW}^{\mathrm{VC}}{ }_{i t}-\mathrm{LnW}_{\mathrm{it}}>0\right)=$ an interaction term that equals $\left(\mathrm{LnW}^{\mathrm{VC}}{ }_{i t}-\mathrm{LnW}_{\mathrm{it}}\right)$ if $\left(\mathrm{LnW}^{\mathrm{VC}}{ }_{i t}-\mathrm{LnW}_{\mathrm{it}}\right)>0$ and zero otherwise.

We refer to this model as "Model 3". Empirical support for H3 would require the coefficient on the $\mathrm{VC}$ pay benchmark anomaly variable, i.e., $\left(\mathrm{LnW}^{\mathrm{VC}}{ }_{\mathrm{it}}-\mathrm{LnW} \mathrm{it}\right)$, to be significantly positive. Empirical support for H3a, the "bidding-up" or "pay ratchet" effect, would require the coefficient on the interaction term that identifies those individual VCs that are underpaid relative to the VC pay benchmark to be significantly positive.

The empirical testing of hypothesis H4, the CEO pay benchmark model which we refer to as "Model 4", also makes use of an augmented version of Model 2 as follows:

$\mathrm{LnW}_{\mathrm{it}+1}-\mathrm{LnW}_{\mathrm{it}}=\operatorname{Model} 2+\beta\left(\mathrm{LnW}^{\mathrm{CEO}}{ }_{\text {it }}-\mathrm{LnW}_{\mathrm{it}}\right)$

Where:

$\left(\mathrm{LnW}^{\mathrm{CEO}}\right.$ it $\left.-\mathrm{LnW}_{\mathrm{it}}\right)=$ the difference between the estimated (natural) log CEO pay benchmark at time $t$ and the (natural) log of the VC's actual pay at time $t$.

As H4 asserts that VC pay awards will constitute a partial adjustment to the (in all cases, higher) pay received by the CEOs of comparable-sized UK firms, empirical support for $\mathrm{H} 4$ would require that the coefficient on the CEO pay anomaly variable be significantly greater than zero but significantly smaller than 1 (which would imply a full adjustment to the apparent underpayment). 
In order to test hypothesis H5, which asserts that remuneration committees will differentially adjust VC pay to the two external pay anomaly variables, we use the following model, which we refer to as "Model 5":

$$
\mathrm{LnW}_{\mathrm{it}+1}-\mathrm{LnW}_{\mathrm{it}}=\operatorname{Model} 2+\beta\left(\mathrm{LnW}^{\mathrm{VC}} \text { it }-\mathrm{LnW}_{\mathrm{it}}\right)+\beta\left(\mathrm{LnW}^{\mathrm{CEO}}{ }_{\text {it }}-\mathrm{LnW}^{\mathrm{VC}} \text { it }\right)
$$

Where:

$\left(\mathrm{LnW}^{\mathrm{VC}}\right.$ it $\left.-\mathrm{LnW}_{\mathrm{it}}\right)=$ the $\mathrm{VC}$ pay benchmark anomaly variable as for Model 3, $\left(\mathrm{LnW}^{\mathrm{CEO}}\right.$ it $-\mathrm{LnW}^{\mathrm{VC}}$ it $)=$ the (natural) log difference between the CEO and VC pay benchmarks.

It will be noted that in Model 5, the CEO pay anomaly variable used in Model 4, i.e., $\left(\mathrm{LnW}^{\mathrm{CEO}}\right.$ it $\left.\mathrm{LnW}_{\mathrm{it}}\right)$, has now been partitioned into two separate variables; namely, $\left(\mathrm{LnW}^{\mathrm{VC}}{ }_{\text {it }}-\mathrm{LnW}_{\mathrm{it}}\right)$, the $\mathrm{VC}$ pay anomaly, and $\left(\mathrm{LnW}^{\mathrm{CEO}}\right.$ it - $\mathrm{LnW}^{\mathrm{VC}}$ it), the difference in the two external pay benchmarks. Empirical support for $\mathrm{H} 5$ requires that the estimated coefficient on the VC pay anomaly variable will be significantly positive, i.e., $\beta_{\left(\mathrm{LnW}^{\mathrm{VC}}{ }_{i t}-\mathrm{LnW}_{\mathrm{it}}\right)}>0$, and the coefficient on the difference between the two pay benchmarks to be significantly positive, i.e. i.e., $\beta_{\left(\mathrm{LnW}^{\mathrm{CEO}}{ }_{i t}-\mathrm{LnW}^{\mathrm{VC}}{ }_{i t}\right)}>0$. However, $\mathrm{H} 5$ also implies that, due to political constraints, the latter coefficient will be significantly smaller than the coefficient on the VC pay anomaly variable, i.e.,

$$
\beta_{\left(\mathrm{LnW}^{\mathrm{VC}}{ }_{\mathrm{it}}-\mathrm{LnW}_{\mathrm{it}}\right)}>\beta_{\left(\mathrm{LnW}^{\mathrm{CEO}}{ }_{\mathrm{it}}-\mathrm{LnW}_{\mathrm{it}}^{\mathrm{VC}}\right)}>0 .
$$

Clearly, in order to estimate models 3 to 5, and hence to test hypotheses $\mathrm{H} 3$ to H5, we need to provide reasonable proxies for the two external pay benchmarks, $\mathrm{W}^{\mathrm{VC}}$ and $\mathrm{W}^{\mathrm{CEO}}$. The most comprehensive VC external pay benchmark proxy available to us is the predicted VC pay levels from estimating the following time t VC pay level model on our UK University dataset:

$$
\begin{aligned}
& \mathrm{LnW}_{\mathrm{it}}=\mathrm{Y}_{\mathrm{t}}+\beta \operatorname{Ln}\left(\text { Income }_{i t-1}\right)+\beta \operatorname{Ln}(\text { Total Studentsit-1 })+\beta \operatorname{Ln}(\text { PG Studentsit-1 })+ \\
& \beta \operatorname{Ln}(\text { Overseas Studentsit-1 })+\beta \operatorname{Ln}(\text { Research Incomeit-1 })+\beta \operatorname{Ln}(\operatorname{Staff}>£ 50 \mathrm{kit})+u_{i t}
\end{aligned}
$$

\section{Where:}

$\mathrm{LnW}_{\mathrm{it}}=$ the (natural) $\log$ of $\mathrm{VC}$ total pay at time $\mathrm{t}$, $\mathrm{Y}_{\mathrm{t}}=$ the constant and $\mathrm{t}-1$ year dummy variables,

$\operatorname{Ln}\left(\right.$ Income $\left._{i t}-1\right)=$ the (natural) $\log$ of University Income (Sales) at time $\mathrm{t}-1$, 
$\operatorname{Ln}($ Total Studentsit-1) = the (natural) $\log$ of total student enrolments at time $\mathrm{t}-1$, Ln(PG Studentsit-1) = the (natural) log of postgraduate student enrolments at time t-1, $\operatorname{Ln}($ Overseas Studentsit-1) $=$ the (natural) $\log$ of overseas (non-UK/EU) student enrolments at time t-1,

$\operatorname{Ln}($ Research Incomeit-1) $=$ the (natural) log of research income at time $\mathrm{t}-1$, $\operatorname{Ln}($ Staff $>£ 50 \mathrm{kit})=$ the (natural) $\log$ of the number of University staff earning more than $£ 50,000$ at time $\mathrm{t}$, $u_{i t}=$ the regression residuals.

The ordinary least squares (OLS) and generalised least squares (Random Effects) estimates of equation (6) are shown in Table 3, under the columns headed "VC Pay Model 2". It will be noted that the two estimation methods produce almost identical coefficients and that the model is able to account for slightly more than $50 \%$ of the cross-sectional variation in (logged) VC pay levels. However, with the exception of the high earning staff and University size (Income) variables, none of the other University characteristics are significantly positively related to VC pay levels. Moreover, due to high correlations between each of the variables ${ }^{10}$, three have negative estimated coefficients. Though it makes no discernable difference to the reported results, for these reasons we use the predicted values estimated from the more parsimonious Model 1 as our proxy for the VC external pay benchmark. Whilst this model includes only the total income variable, it is efficient since it is still successful at explaining almost $48 \%$ of the cross sectional variation in VC pay. Perhaps more importantly, its limited information requirements can be expected to more closely replicate the limited comparative VC pay data provided to and/or capable of being processed by university remuneration committees.

To empirically evaluate hypotheses $\mathrm{H} 4$ and $\mathrm{H} 5$, we also need to provide an equivalent empirical proxy for the external CEO pay benchmark, i.e., the pay that VCs would receive if they were being paid on a comparable basis to other UK CEOs running similar-sized UK companies. This is accomplished by first estimating the following CEO pay level model using 1996 to 2001 data relating to all non-financial UK listed firms available on the Datastream database with a sales turnover of between $£ 20$ million and £1billion (a total of 3258 firm-years): 
$\mathrm{LnW}_{\mathrm{it}}=\mathrm{Y}_{\mathrm{t}}+\beta \operatorname{Ln}($ SALES it-1 $)+\beta($ Shareholder Returnsit $)+\mathrm{u}_{\mathrm{it}}$

Where:

$\mathrm{LnW}_{\mathrm{it}}=$ natural $\log$ of total cash (salary plus cash bonuses) pay for CEO $\mathrm{i}$ in time $\mathrm{t}$,

$\mathrm{Y}_{\mathrm{t}}=$ the constant and $\mathrm{t}-1$ year dummy variables to control for time-varying common effects, $\operatorname{Ln}\left(\right.$ SALES $\left._{i t-1}\right)=$ natural $\log$ of total sales of firm $\mathrm{i}$ in time $\mathrm{t}-1$, and,

Shareholder Returnsit $=$ total returns (dividend yield plus share price changes adjusted for capital splits in time t).

As UK Universities are clearly unlisted and not-for-profit organisations, we ignore the element of CEO pay related to shareholder returns and calculate the predicted external CEO pay benchmark, $\mathrm{Ln}\left(\mathrm{W}^{\mathrm{CEO}}\right.$ it $)$, as follows:

$$
\operatorname{Ln}\left(\mathrm{W}^{\mathrm{CEO}} \text { it }\right)=\mathrm{Y}_{\mathrm{t}}+\beta \operatorname{Ln}(\text { Incomeit-1 })
$$

Where:

$\mathrm{Y}_{\mathrm{t}}+\beta$ are the estimated parameters of the constant, time dummies and Sales variables estimated from (7) and Ln(Incomeit-1) is the natural log of University i's total income in time t-1.

$\mathrm{Ln}\left(\mathrm{W}^{\mathrm{CEO}}\right.$ it $)$ is therefore the estimated pay at time $\mathrm{t}$ that a $\mathrm{VC}$ would receive if $\mathrm{s} / \mathrm{h}$ e was paid on the same sales turnover (Income) basis as other UK CEOs.

The first column of Table 3 contains the estimated parameters of our Datastream derived CEO pay level benchmark model detailed in equation (7). As with many previous studies, this relatively simple pay level model performs quite well in terms of explanatory power (adjusted $\mathrm{R}^{2}$ $=33.5 \%$ ), particularly as it has been estimated using a very heterogeneous sample of firms in terms of both sectors and sizes. Consistent with previous studies, CEO cash pay (salary and bonuses) is strongly positively related to firm size (sales turnover) and increasing annual intercepts (year dummies) over time that reflect the general rises in CEO pay unrelated to either changes in firm size or performance. The shareholder returns variable is quite small in magnitude and, moreover, statistically insignificant. Again, this is consistent with many previous studies that have shown shareholder returns and accounting performance measures to be of relatively little statistical or economic importance in explaining the level of CEO pay across any relatively heterogeneous sample of firms. 
For comparison purposes, in the next 2 columns, we provide estimates of the same pay level model (excluding the shareholder returns variable) but using UK VC and university data. The first VC pay model includes all observations for which the relevant VC and University data are available. Comparison with the Datastream CEO pay level model reveals a slightly higher intercept and smaller and less significant dummy variable coefficients. The main difference however lies in the magnitude of the size variable coefficient, which at less than 0.1 is approximately only $40 \%$ of the size of the estimated Datastream parameter. Even so, as can be seen from the results presented in the third column, our second VC model, which excludes 3 institutions (18 observations) that were the largest and most consistent outliers, the slope coefficient on the size variable was biased downwards by a few unrepresentative observations. The three institutions excluded were certainly a-typical, namely, Oxford and Cambridge (whose VC's appeared to be extremely underpaid given the large size of their respective institutions) and the London Business School (whose Director was exceptionally well-paid relative to all other VCs, particularly so given the relatively small size of LBS). As can be seen from Table 3, excluding these outliers greatly improves the explanatory power of the model and results in an increase in the size and significance of the size variable coefficient and a corresponding fall in the intercept. As mentioned above, the predicted VC pay levels derived from Model 1 (excluding the outliers) constitutes our external VC pay benchmark, $\mathrm{Ln}\left(\mathrm{W}^{\mathrm{VC}}{ }_{i t}\right)$.

It will be recalled that Model 5 examines the relative influence of both external pay benchmarks. The correlation coefficient of 0.94 between our estimates of $\mathrm{Ln}\left(\mathrm{W}^{\mathrm{CEO}}{ }_{i t}\right)$ and $\mathrm{Ln}\left(\mathrm{W}^{\mathrm{VC}}\right.$ it $)$, shown in section A of Table 2, indicates that, despite the large difference in the means of these two external pay benchmarks and the differing Model 1 Datastream and VC parameters shown in the Table 3 pay level estimates, they appear to be close substitutes for one another. As can be seen from Section B of Table 2, the correlation between the two external pay benchmark measures falls to 0.79 when these pay benchmarks are expressed as deviations from the VC's actual pay. Even so, this still very high level of correlation ought not to cause estimation problems since the CEO pay benchmark variable used in this model, $\left(\mathrm{LnW}^{\mathrm{CEO}}{ }_{i t}-\mathrm{LnW}^{\mathrm{VC}}{ }_{i t}\right)$, measures only the difference between the two external pay benchmarks and this is uncorrelated with the VC pay benchmark variable also included in the estimating equation. 
Though in practice, actual pay levels may be related to a potentially large number of observable and unobservable individual human capital and organisational factors, in pay change models these factors become irrelevant if they do not alter over time, i.e., they are fixed effects. This ability to ignore such fixed effects justifies our use of the parsimonious pay change models. However, the assumption of unchanging human capital attributes is clearly violated when there has been a change in the individual holding the post of VC. As new VCs tend to be younger and less experienced than the outgoing (usually retiring) $\mathrm{VC}$, the change in $\mathrm{VC}$ is likely to be associated with a reduction in VC pay that needs to be controlled for. Our reported empirical VC pay change estimates all include an additional "change in VC" dummy variable which is coded 1 if there has been a change in $\mathrm{VC}$ between time $\mathrm{t}$ and $\mathrm{t}+1$ and zero otherwise. ${ }^{11}$

\section{Empirical Results}

Table 4 presents the main empirical findings of our analysis of changes in VC pay. In all the individual model estimates, the change in VC dummy variable is, as expected, statistically negative at $1 \%$ levels of confidence. The first column of Table 4, Model 2, contains the empirical estimates to evaluate hypotheses $\mathrm{H} 1$ and $\mathrm{H} 2$. Hypothesis $\mathrm{H} 1$, that VC pay changes ought to be positively related to one or more of the University performance variables, is not supported. Though the overall explanatory power of the model is statistically significant at $1 \%$ confidence levels, very little of this explanatory power results from the inclusion of the performance variables. Rather, the explanatory power of Model 2 comes almost wholly from the inclusion of the change in $\mathrm{VC}$ dummy variable and the internal pay comparison variable, the change in the proportion of staff earning greater than $£ 50,000$. This latter variable it will be recalled is included to evaluate $\mathrm{H} 2$, that $\mathrm{VC}$ pay awards would be influenced by internal pay pressures. As the positive coefficient on this variable is statistically significant at $1 \%$ levels of confidence, this provides empirical support for hypothesis H2. It will be noted from the other models shown in Table 4 that the above results in relation to the lack of statistical support for $\mathrm{H} 1$ and the strong statistical support for $\mathrm{H} 2$ are robust to changes in the model specifications.

The empirical estimates presented under the column headed Model 3 in Table 4 provide the evidence to evaluate hypotheses $\mathrm{H} 3$, that VC pay awards would be positively related to observable deviations from the external VC pay benchmark, and H3a, there being a "bidding up" of VC pay due to relatively underpaid VCs experiencing a larger adjustment in pay than similarly overpaid VCs. The results provide statistical support for H3, i.e., the coefficient of 0.241 on the 
VC pay anomaly variable is significantly positive. However, there appears to be no support for $\mathrm{H} 3 \mathrm{a}$, the bidding up hypothesis, since the estimated coefficient on the underpaid VC interaction term is actually negative, though not significantly so. Whilst these Model 3 empirical estimates suggest that no bidding up of VC pay seems to have occurred due to remuneration committees awarding relatively underpaid VCs more generous pay rises, the significantly positive constant term indicates that VC's generally may have experienced pay rises of approximately $7 \%$ per annum completely independently of university performance and irrespective of their relative pay levels.

Model 4, which includes the external CEO pay benchmark anomaly variable, evaluates hypothesis $\mathrm{H} 4$, the influence upon VC pay awards resulting from remuneration committees making a partial adjustment of VC pay towards the pay levels typically received by the CEOs of comparable sized UK firms. Though the overall explanatory power of the model is somewhat lower than for model 3, the reported results are consistent with $\mathrm{H} 4$ as the estimated coefficient of 0.155 on this CEO pay benchmark variable is statistically significant at $1 \%$ confidence levels. However, as indicated earlier, the correlation between the VC and CEO pay benchmarks is very high and the statistical significance of the CEO pay benchmark variable may simply be a function of this high correlation between the two variables. The specification of Model 5 allows for the evaluation of whether the CEO pay benchmark variable has any incremental explanatory power when the VC pay benchmark variable is included in the estimating equation. Model 5 also evaluates the more specific predictions associated with hypothesis H5. Hypothesis H5 predicts that the estimated coefficient on the difference between the VC and CEO pay benchmarks ought to be significantly positive but, due to perceived political constraints upon VC pay rises, of a much smaller magnitude than the estimated coefficient on the VC pay anomaly variable. As can be seen from the results shown in Table 4, the coefficient on the VC pay anomaly variable is almost identical to the coefficient estimated from Model 3 (0.233 versus 0.241$)$ and, though the coefficient on the difference between the two pay benchmarks is positive it is not statistically significant at conventional levels of confidence. On the basis of these results it might be concluded that the pay received by other UK CEOs has no incremental explanatory power relative to the VC pay anomaly variable. Nevertheless, Model 5 includes the five university performance variables and the constant term, all of which appear not to be statistically related to VC pay awards. The more parsimonious Model 5a, which excludes these irrelevant variables and hence focuses solely on evaluating the explanatory power of the three (one internal and two external) pay comparison variables, provides results that are consistent with hypothesis H5. In 
this more efficient model, the coefficient of 0.065 on the difference between the two external pay comparisons is highly significant and, as suggested by H5, is significantly smaller than the 0.233 estimated coefficient on the VC pay anomaly variable.

The results presented in Table 4 appear to suggest that VC pay awards are determined solely with reference to internal and external pay comparisons, but that the impact of the latter may be subdued somewhat due to political constraints. Nevertheless, it will be recalled from the descriptive statistics shown in Table 1 that the UK university sector includes a wide variety of institutions in terms of size, research income, the proportion of highly paid staff and the composition of their student intakes. This cross-sectional heterogeneity implies that individual universities have very different business models, academic missions and relative exposures to internal and external pay pressures. For example, the high status, research-intensive, pre-1992 universities are likely to view increases in research income more favourably than income from increased undergraduate numbers even though, given the competition for high quality researchers, this is also likely to increase average staff costs. In order to check the robustness of our results and to test the possibility that remuneration committees of the pre-1992 universities may be more susceptible to internal and external pay pressures and/or apply very different performance criteria in regard to how they remunerate their VCs, in Table 5 we re-estimate models 5 and 5a for the two sub-groups of universities, i.e., the research-intensive pre-1992 universities and the post-1992 institutions.

As can be seen from Table 5, the results for Model 5 for the two groups of universities are slightly different, particularly in regard to the size, signs and significance levels of some of the university performance measures. For example, for the pre-1992 universities we now obtain significantly positive coefficients in respect of the changes in postgraduate students and for changes in research income. As regards the post-1992 universities, we now obtain a highly significant positive coefficient on the change in total student numbers, whilst there is a significantly negative coefficient on the change in postgraduate students. Moreover, for the post1992 universities, there appears to be no significantly positive relationship between the change in other highly paid staff and VC pay awards. As can be seen from the "coefficient differences" column, the differences between the two groups of universities in terms of total students, postgraduates and research income are statistically significant at $5 \%$ or better confidence levels. The more parsimonious Model 5a results for the two subgroups also shown in Table 5 confirm the lack of statistical significance in respect of the internal pay comparison measure for the post- 
1992 universities though, as indicated in the coefficient differences column neither this nor any of the remaining coefficient differences are statistically significant.

\section{Concluding Remarks}

This paper has empirically examined UK university VC pay awards over the 6 year period to 2002. Despite significant differences between the pre-1992 and post-1992 universities in terms of total income growth, the growth in other high paid employees, success at attracting research income and the proportions of postgraduate and overseas students, for both groups average CV pay was approximately $£ 100,000$ in 1997 . Consistent with their faster average income growth rates, over the subsequent 5 years the pay of the pre-1992 university VC's increased at a slightly faster rate than that of the post-1992 University VCs. By 2002 the pre-1992 university VC's were earning on average $£ 143,400$, which was some $£ 10,000$ more than their counterparts in the post1992 sector.

Nevertheless, average VC pay even in the pre-1992 sector has continued to fall further behind that of a far more relevant comparison group, namely, the pay of CEOs of comparable-sized UK enterprises. On the basis of a pay level model calibrated on UK CEO and Datastream listed firm data over the same period, UK VCs appear to be significantly underpaid relative to CEOs running UK firms that generate similar sales revenues. VC pay awards are however influenced by both internal pay comparisons, i.e., the change in the number of other highly paid staff in their institutions, and external pay comparisons since we document a highly significant (partial) adjustment to prior period CEO and other VC external labour market pay anomalies. These highly significant partial adjustments of VC pay to prior period external labour market pay anomalies are robust to (i.e., unaffected by) the inclusion of other performance and University specific variables in the estimating equation.

The partial adjustment implied by the small but significantly positive coefficient on the difference between the two external pay benchmarks suggests that average VC pay increases have been constrained throughout the period. Given the relatively small sums of money involved, even a doubling of VC pay would have little discernable impact on the finances of their universities or their ability to increase the pay of other university employees. Hence, financial constraints are clearly not the primary cause of the relatively low VC salaries in the UK. Rather, we have interpreted these results as reflecting the desire of remuneration committees to avoid public 
criticism, particularly from Academic trade unions, regarding awarding pay rises to VCs that in percentage terms consistently exceed that of their academic and other professional employees. Though the academic trade unions are perhaps correct in claiming that UK academic salaries also need to rise, their continued insistence on national pay bargaining appears to be a major constraint upon increasing pay levels in the wealthier and more competitive research intensive universities. Indeed, the example of the London Business School, which in the early 1990's broke away from this system of national bargaining, demonstrates as much. In 2002 more than $100 \%$ of LBS's full time equivalent academic staff (i.e., even many of its part time staff) earned more than $£ 50,000$.

The continuing low pay of VCs and the highly intemperate tone of the criticisms of university remuneration committees and VCs listed in Figure 1 are, of course, likely to be self-defeating if they have the effect of reducing the pool of talented individuals willing to take on the job of VC. Perhaps equally serious for the future of UK universities, such criticisms could lead to fewer distinguished outsiders being willing to freely give their time to sit on university Councils. It is clear that in an era of increasing international competition and declining State funding, universities need and deserve the same high quality leadership and governance skills as any other organisation. We find ourselves in agreement with the sentiments expressed by Oswald (reproduced in Figure 1), namely that the criticisms to date of VC pay rises are "inherently childish" and that for the future health of the UK university sector, it is imperative that the salaries of VCs become "competitive with those paid outside academia." 


\section{References}

Baimbridge, M. and C. Simpson (1996), 'Rewards to Academia: the remuneration of vice chancellors and principals', Applied Economics, 28, pp 631-639.

Barkema, H.G. \& Gomez-Mejia, L.R. (1998), Managerial compensation and firm performance: a general research framework, Academy of Management Journal, Vol. 41 (2), April: 135-145.

Bebchuk and Fried (2003), 'Executive Compensation as an Agency Problem', Working Paper 9813, National Bureau of Economic Research.

Cadbury Report (1992) Committee on the Financial Aspects of Corporate Governance, Financial Reporting Council, London.

Combined Code, (2002) The Committee on Corporate Governance: The Combined Code, Gee \& Co, London.

Committee of University Chairmen (CUC) (2002), 'Guide for Members of Governing Bodies of Universities and Colleges in England, Wales and Northern Ireland', April, 2002.

Committee of University Chairmen (CUC) (2004), 'Guide for Members of Higher Education Governing Bodies in the UK: Governance Code of Practice and General Principles', November 2004.

Conyon, M.J., P. Gregg and S. Machin (1995) 'Taking Care of Business: executive compensation in the UK', Economic Journal, 105, 704-715.

Conyon, M.J. (2006), Executive Compensation and Incentives, Academy of Management Perspectives, Vol. 20, 1, February, pp. 25-44.

Conyon, M.J. and Murphy, K. (2000), "The Prince and the Pauper? CEO Pay in the United States and United Kingdom“, The Economic Journal, Vol. 110, November, 2000, pp. 640-671.

Conyon, M.J., Peck, S.I., Read, L.E. and Sadler, G.V. (2000) 'The Structure of Executive Compensation Contracts: UK Evidence', Long Range Planning, 33: 478-503.

Cragg, M. and Dyck, I. (2000), Executive Pay and UK Privatisation: The Demise of 'One Country, Two Systems', Journal of Business Research, 47, pp.3-18.

Dolton, P.J. and A. Ma (2003), ' CEO Pay in the Public Sector: the case of vice chancellors in UK universities', University of Newcastle Discussion Paper, January, 2003.

Ezzamel, M. and R. Watson (1998) 'Market Comparison Earnings and the Bidding-up of Executive Cash Compensation: Evidence from the UK', Academy of Management Journal 41, 221-231.

Ezzamel, M. and R. Watson (2002) 'Pay Comparability Across and Within UK Boards: an empirical analysis of the cash pay awards to CEO and other board members', Journal of Management Studies, 39, 207-232. 
Forbes, W. and R.Watson (1993) 'Managerial remuneration and corporate governance: a review of the issues and evidence and the Cabury Committee's proposals', Accounting and Buisness Research 23, 331-38.

Greenbury Report (1995) Directors' Remuneration - Report of a Study Group Chaired by Sir Richard Greenbury, Gee \& Co., London.

Hempel Report (1998) The Committee on Corporate Governance - Final Report of the Study Group Chaired by Sir Ronald Hampel, Gee \& Co., London.

Institute of Directors (1995) The Remuneration of Directors: A Framework for Remuneration Committees, London, Institute of Directors.

Main, B.G.M. and J. Johnston (1993) 'Remuneration Committees and Corporate Governance' Accounting and Business Research 23, 351-62.

Martin, J. (2001), 'Golf Tournaments and CEO Pay - Unraveling the Mysteries of Executive Pay’, Journal of Applied Corporate Finance, 14, Fall, pp. 22-34.

Lazear, E.D. (1989), "Pay Equality and Industrial Politics", Journal of Political Economy, Vol. 97, June, pp. 561-580.

Lazear, E.D. and Rosen, S. (1981), "Rank Order Tournaments as Optimum Labor Contracts", Journal of Political Economy, Vol. 89, pp. 841-864.

Ogden, S. and R. Watson (2004), 'Remuneration Committees and CEO Pay in the UK privatised water industry', Socio-Economic Review, Vol. 2, pp. 33-63.

O'Reilley, C.A., Main, B.G.M. and.G.S. Crystal (1988) 'CEO Salaries as Tournaments and Social Comparisons: A Tale of Two Theories', Administrative Science Quarterly 33, 257-274.

Stiles P. and B. Taylor (2000) Boards at Work, Oxford University Press, Oxford. 
Table 1

Descriptive Statistics by Year

(Standard Deviations in Parenthesis)

\begin{tabular}{|c|c|c|c|c|c|c|}
\hline Variable Name & 1997 & 1998 & 1999 & 2000 & 2001 & 2002 \\
\hline Number of Observations by Year & 104 & 105 & 107 & 105 & 110 & 110 \\
\hline Number of Pre-1992 Universities & 63 & 64 & 65 & 63 & 66 & 66 \\
\hline Number of Post-1992 Universities & 41 & 41 & 42 & 42 & 44 & 44 \\
\hline Total Income (£m’s) & $\begin{array}{l}94.8 \\
(59.2)\end{array}$ & $\begin{array}{c}99.3 \\
(65.8)\end{array}$ & $\begin{array}{r}103.7 \\
(71.0)\end{array}$ & $\begin{array}{l}108.6 \\
(80.0)\end{array}$ & $\begin{array}{r}115.4 \\
(82.5)\end{array}$ & $\begin{array}{r}123.9 \\
(87.3)\end{array}$ \\
\hline Mean for Pre-1992 Universities & 110.6 & 116.9 & 123.4 & 131.6 & 140.1 & 149.6 \\
\hline Mean for Post-1992 Universities & 69.9 & 72.1 & 73.9 & 74.2 & 75.8 & 76.5 \\
\hline Total Research Income (£m’s) & $\begin{array}{c}13.1 \\
(20.5)\end{array}$ & $\begin{array}{c}14.1 \\
(23.0)\end{array}$ & $\begin{array}{c}15.2 \\
(25.1)\end{array}$ & $\begin{array}{r}16.5 \\
(26.6)\end{array}$ & $\begin{array}{l}17.8 \\
(29.4)\end{array}$ & $\begin{array}{l}21.9 \\
(33.2)\end{array}$ \\
\hline Mean for Pre-1992 Universities & 20.1 & 21.9 & 23.7 & 25.8 & 27.8 & 34.2 \\
\hline Mean for Post-1992 Universities & 2.0 & 2.2 & 2.3 & 2.6 & 2.8 & 2.9 \\
\hline $\begin{array}{l}\text { Total (FTE) Staff (Academic, } \\
\text { Academic-related and Administrative) }\end{array}$ & $\begin{array}{l}887.6 \\
(611.7)\end{array}$ & $\begin{array}{l}889.9 \\
(619.3)\end{array}$ & $\begin{array}{l}917.8 \\
(640.6)\end{array}$ & $\begin{array}{r}974.7 \\
(737.5)\end{array}$ & $\begin{array}{l}968.2 \\
(758.8)\end{array}$ & $\begin{array}{l}1058.0 \\
(782.2)\end{array}$ \\
\hline Mean for Pre-1992 Universities & 1009.7 & 1019.0 & 1042.9 & 1119.7 & 1127.0 & 1255.4 \\
\hline Mean for Post-1992 Universities & 695.4 & 693.2 & 728.8 & 757.3 & 730.0 & 752.7 \\
\hline $\begin{array}{l}\text { Nationally Agreed Pay Level for point } \\
18 \text { Lecturer B scale (pre-1992 } \\
\text { Universities) (£’s) }\end{array}$ & 27,985 & 28,454 & 30,036 & 30,967 & 31,896 & 32,537 \\
\hline Number of Staff Earning $>£ 50,000$ & $\begin{array}{c}34.4 \\
(51.2)\end{array}$ & $\begin{array}{l}40.9 \\
(58.0)\end{array}$ & $\begin{array}{l}48.6 \\
(65.8)\end{array}$ & $\begin{array}{l}62.2 \\
(74.8)\end{array}$ & $\begin{array}{l}73.1 \\
(85.2)\end{array}$ & $\begin{array}{l}88.0 \\
(98.9)\end{array}$ \\
\hline Mean for Pre-1992 Universities & 53.1 & 61.1 & 71.0 & 91.3 & 106.2 & 125.5 \\
\hline Mean for Post-1992 Universities & 6.7 & 9.1 & 14.1 & 18.6 & 23.4 & 31.2 \\
\hline Number of Staff Earning $>£ 100,000$ & & $\begin{array}{l}2.3 \\
(4.8)\end{array}$ & $\begin{array}{l}4.6 \\
(10.4)\end{array}$ & $\begin{array}{l}5.8 \\
(12.8)\end{array}$ & $\begin{array}{l}6.1 \\
(13.9)\end{array}$ & $\begin{array}{l}7.7 \\
(16.1)\end{array}$ \\
\hline Mean for Pre-1992 Universities & & 3.7 & 7.5 & 9.5 & 10.0 & 12.6 \\
\hline Mean for Post-1992 Universities & & 0.1 & 0.2 & 0.3 & 0.2 & 0.4 \\
\hline Total (FTE) Students (000’s) & $\begin{array}{r}11.4 \\
(7.8)\end{array}$ & $\begin{array}{l}12.0 \\
(8.0)\end{array}$ & $\begin{array}{l}12.1 \\
(8.4)\end{array}$ & $\begin{array}{l}12.2 \\
(8.6)\end{array}$ & $\begin{array}{l}13.1 \\
(8.2)\end{array}$ & $\begin{array}{l}13.7 \\
(8.7)\end{array}$ \\
\hline Mean for Pre-1992 Universities & 11.3 & 11.6 & 11.8 & 12.0 & 12.4 & 13.2 \\
\hline Mean for Post-1992 Universities & 12.4 & 12.6 & 12.7 & 12.5 & 14.2 & 14.6 \\
\hline
\end{tabular}




\begin{tabular}{|c|c|c|c|c|c|c|}
\hline Percentage of Post Graduate Students & $\begin{array}{l}21.8 \\
(17.4)\end{array}$ & $\begin{array}{l}21.9 \\
(17.2)\end{array}$ & $\begin{array}{l}22.1 \\
(17.3)\end{array}$ & $\begin{array}{l}22.3 \\
(17.3)\end{array}$ & $\begin{array}{l}23.2 \\
(17.0)\end{array}$ & $\begin{array}{l}23.5 \\
(17.2)\end{array}$ \\
\hline Mean for Pre-1992 Universities & 27.7 & 27.8 & 28.2 & 28.3 & 29.3 & 29.6 \\
\hline Mean for Post-1992 Universities & 11.9 & 12.5 & 12.7 & 13.42 & 14.0 & 14.3 \\
\hline $\begin{array}{l}\text { Percentage of Overseas (non-UK/EU) } \\
\text { Students }\end{array}$ & $\begin{array}{l}17.4 \\
(12.8)\end{array}$ & $\begin{array}{l}17.8 \\
(11.9)\end{array}$ & $\begin{array}{l}18.0 \\
(12.2)\end{array}$ & $\begin{array}{l}18.2 \\
(12.0)\end{array}$ & $\begin{array}{l}17.7 \\
(11.9)\end{array}$ & $\begin{array}{l}18.0 \\
(12.3)\end{array}$ \\
\hline Mean for Pre-1992 Universities & 21.0 & 21.3 & 22.0 & 21.7 & 21.0 & 21.5 \\
\hline Mean for Post-1992 Universities & 11.1 & 12.3 & 11.9 & 12.9 & 12.6 & 12.6 \\
\hline $\begin{array}{l}\text { Vice Chancellor 's Remuneration } \\
\text { (£000’s) }\end{array}$ & $\begin{array}{l}100.2 \\
(15.9)\end{array}$ & $\begin{array}{l}111.5 \\
(17.8)\end{array}$ & $\begin{array}{l}116.9 \\
(20.8)\end{array}$ & $\begin{array}{r}123.4 \\
(22.0)\end{array}$ & $\begin{array}{l}135.7 \\
(34.6)\end{array}$ & $\begin{array}{l}139.5 \\
(27.0)\end{array}$ \\
\hline Mean for Pre-1992 Universities & 100.5 & 114.6 & 121.4 & 127.9 & 141.9 & 143.4 \\
\hline Mean for Post-1992 Universities & 99.9 & 106.5 & 110.0 & 116.7 & 126.3 & 133.7 \\
\hline $\begin{array}{l}\text { Datastream Predicted Average t-1 Vice } \\
\text { Chancellor's Pay ( } £ 000 \text { 's) }\end{array}$ & $\begin{array}{l}203.5 \\
(27.9)\end{array}$ & $\begin{array}{l}257.3 \\
(36.6)\end{array}$ & $\begin{array}{l}272.8 \\
(38.3)\end{array}$ & $\begin{array}{l}305.2 \\
(44.8)\end{array}$ & $\begin{array}{l}319.6 \\
(48.3)\end{array}$ & $\begin{array}{l}342.7 \\
(52.8)\end{array}$ \\
\hline Mean for Pre-1992 Universities & 210.2 & 266.2 & 282.8 & 317.0 & 331.7 & 356.9 \\
\hline Mean for Post-1992 Universities & 193.0 & 243.6 & 257.7 & 287.3 & 301.3 & 321.2 \\
\hline $\begin{array}{l}\text { Average t-1 CEO Pay ( } £ 000 \text { ’s) } \\
\text { (for Datastream Companies }<£ 1 \text { billion } \\
\text { Sales) }\end{array}$ & $\begin{array}{c}283.0 \\
(187.2)\end{array}$ & $\begin{array}{c}296.7 \\
(195.0)\end{array}$ & $\begin{array}{l}315.7 \\
(212.8)\end{array}$ & $\begin{array}{l}330.8 \\
(260.4)\end{array}$ & $\begin{array}{l}377.6 \\
(293.4)\end{array}$ & $\begin{array}{c}403.4 \\
(315.7)\end{array}$ \\
\hline $\mathrm{N}=$ & 384 & 408 & 314 & 488 & 405 & 412 \\
\hline $\begin{array}{l}\text { Total t-1 Sales ( } £ 1 \text { millions) } \\
\text { (for Datastream Companies }<£ 1 \text { billion } \\
\text { Sales) }\end{array}$ & $\begin{array}{l}200.2 \\
(219.3)\end{array}$ & $\begin{array}{l}203.5 \\
(216.5)\end{array}$ & $\begin{array}{l}226.9 \\
(221.3)\end{array}$ & $\begin{array}{l}199.6 \\
(208.6)\end{array}$ & $\begin{array}{r}216.9 \\
(223.1)\end{array}$ & $\begin{array}{r}219.7 \\
(257.6)\end{array}$ \\
\hline $\mathrm{N}=$ & 384 & 408 & 314 & 488 & 405 & 412 \\
\hline
\end{tabular}

Notes:

The University pay and performance data relates to all UK higher education institutions with annual turnover in excess of 220 million for which we obtained the three consecutive years of data required to estimate the pay change models presented in Tables 4 and 5.

The university performance data was obtained from the Higher Education Statistical Service (HESA) Year Books and the VC pay information was obtained from the THES and, in a few cases, from the published Financial Statements of individual universities.

For comparison purposes and for estimating the external CEO market pay anomaly variable, comparable pay and performance data relating to UK firms on the Datastream database was obtained. The Datastream variables above and the CEO pay level model shown in Table 3 was estimated using a total of 3258 firm-years over the period 1995 to 2001, which includes all CEOs of other UK listed non-financial firms with at least 100 full-time equivalent employees, a turnover between $£ 20$ million and $£ 1$ billion per annum and which had a minimum of 2 years of complete data required to estimate the CEO pay level model. 
Table 2

Correlation Matrix

Section A: Pay Level and Performance Variables

\begin{tabular}{|c|c|c|c|c|c|c|c|c|c|c|}
\hline 1. $\operatorname{Ln}(\mathrm{W})_{\mathrm{t}}$ & 1.00 & & & & & & & & & \\
\hline 2. $\mathrm{Ln}\left(\mathrm{W}^{\mathrm{CEO}}\right)_{\mathrm{t}}$ & 0.67 & 1.00 & & & & & & & & \\
\hline 3. $\mathrm{Ln}\left(\mathrm{W}^{\mathrm{VC}}\right)_{\mathrm{t}}$ & 0.71 & 0.94 & 1.00 & & & & & & & \\
\hline 4. Ln(Total Sales) t-1 & 0.43 & 0.71 & 0.61 & 1.00 & & & & & & \\
\hline 5. Ln $(\text { Staff earning }>£ 50 \mathrm{k})_{\mathrm{t}}$ & 0.66 & 0.80 & 0.93 & 0.43 & 1.00 & & & & & \\
\hline 6. Ln (PG Students) $)_{\mathrm{t}-1}$ & 0.25 & 0.46 & 0.41 & 0.64 & 0.28 & 1.00 & & & & \\
\hline 7. Ln (Research income $)_{t-1}$ & 0.23 & 0.42 & 0.41 & 0.57 & 0.34 & 0.50 & 1.00 & & & \\
\hline 8. Ln(non-UK/EU students) $)_{\mathrm{t}-1}$ & 0.10 & 0.24 & 0.22 & 0.34 & 0.16 & 0.52 & 0.29 & 1.00 & & \\
\hline 9. Ln(Total FTE Students) $)_{\mathrm{t}-1}$ & 0.18 & 0.32 & 0.24 & 0.46 & 0.12 & 0.71 & 0.12 & 0.47 & 1.00 & \\
\hline \multirow{2}{*}{$\begin{array}{l}\text { 10. Type of University } \\
(\text { pre-1992 =1) }\end{array}$} & 0.11 & 0.18 & 0.22 & 0.27 & 0.23 & 0.33 & 0.55 & 0.09 & -0.13 & 1.00 \\
\hline & 1 & 2 & 3 & 4 & 5 & 6 & 7 & 8 & 9 & 10 \\
\hline
\end{tabular}

Section B: Pay Change and Performance Variables

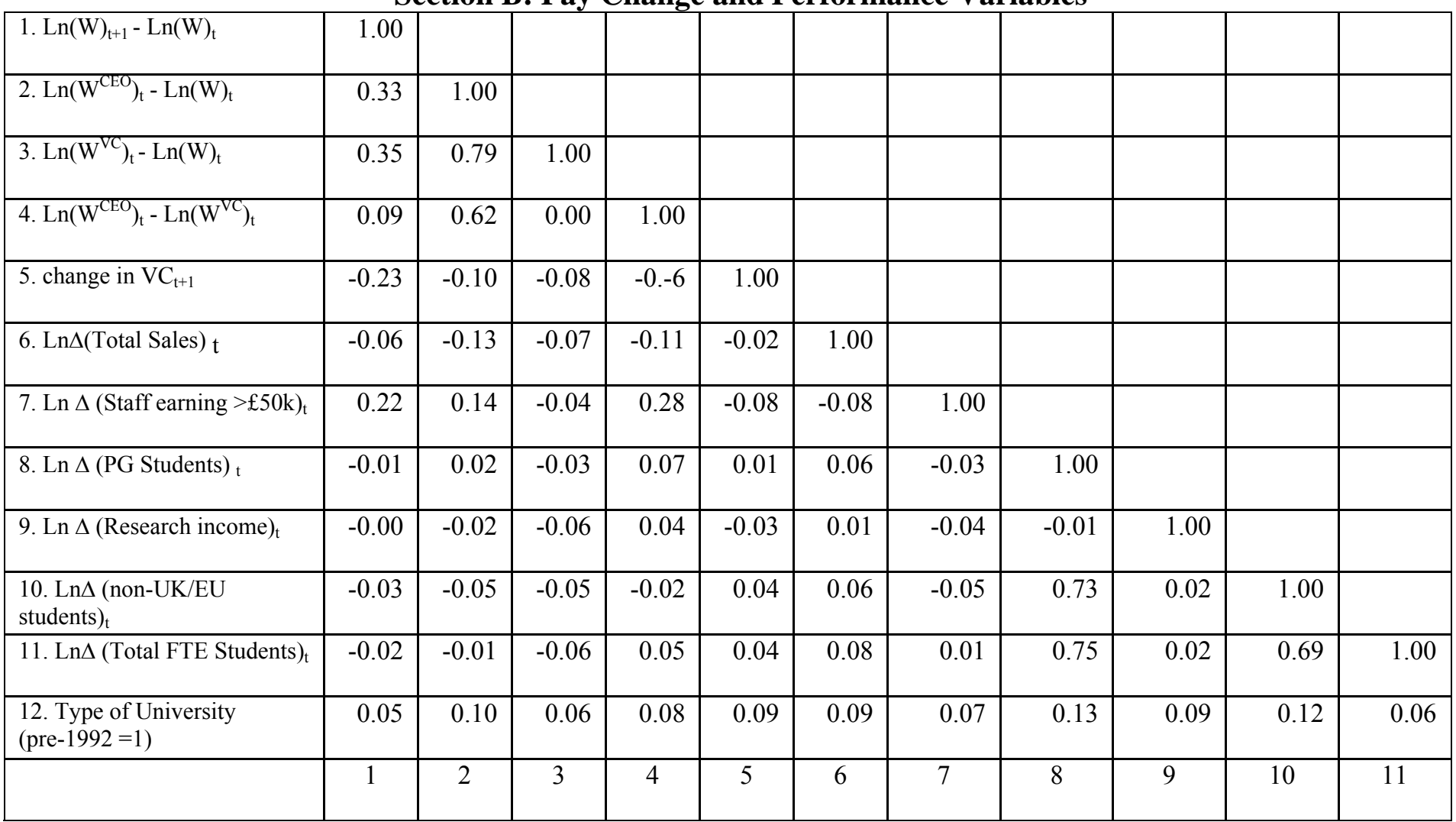


TABLE 3

ESTIMATION OF CEO and VC PAY LEVELS 1997 TO 2002

Dependent Variable $=\mathrm{Ln}(\mathrm{W})_{\mathrm{t}}$,

where $\mathrm{W}_{\mathrm{t}}=\mathrm{VC}$ or Datastream CEO Total Cash (salary plus bonuses) Pay in time $\mathrm{t}$

\begin{tabular}{|c|c|c|c|c|c|}
\hline Independent Variable & $\begin{array}{l}\text { Datastream } \\
\text { Pay Level } \\
\text { Model } 1\end{array}$ & $\begin{array}{l}\text { VC Pay } \\
\text { Model } 1 \\
\text { (all } \\
\text { Universities) }\end{array}$ & $\begin{array}{l}\text { VC Pay } \\
\text { Model } 1 \\
\text { (excl } \\
\text { outliers) }\end{array}$ & $\begin{array}{l}\text { VC Pay } \\
\text { Model } 2\end{array}$ & $\begin{array}{l}\text { VC Pay Mo } \\
\text { (Random E } \\
\text { Estimates) }\end{array}$ \\
\hline Constant & $\begin{array}{c}2.577 \\
(32.66)^{* * *}\end{array}$ & $\begin{array}{l}3.462 \\
(23.46) * * *\end{array}$ & $\begin{array}{c}3.050 \\
(24.08)^{* * *}\end{array}$ & $\begin{array}{l}3.625 \\
(19.73)^{* * *}\end{array}$ & $\begin{array}{c}3.485 \\
(15.42)^{* * *}\end{array}$ \\
\hline Year Dummy 1998 & $\begin{array}{l}0.223 \\
(7.85)^{* * *}\end{array}$ & $\begin{array}{c}0.039 \\
(1.84)^{*}\end{array}$ & $\begin{array}{c}0.036 \\
(1.76)^{*}\end{array}$ & $\begin{array}{c}0.038 \\
(1.89)^{*}\end{array}$ & $\begin{array}{l}0.039 \\
(3.17)^{* * *}\end{array}$ \\
\hline Year Dummy 1999 & $\begin{array}{l}0.271 \\
(9.85)^{* * *}\end{array}$ & $\begin{array}{l}0.142 \\
(6.88)^{* * *}\end{array}$ & $\begin{array}{l}0.136 \\
(7.11)^{* * *}\end{array}$ & $\begin{array}{r}0.003 \\
(0.09)\end{array}$ & $\begin{array}{l}0.073 \\
(3.35)^{* * *}\end{array}$ \\
\hline Year Dummy 2000 & $\begin{array}{l}0.372 \\
(12.89)^{* * *}\end{array}$ & $\begin{array}{l}0.185 \\
(8.58)^{* * *}\end{array}$ & $\begin{array}{l}0.175 \\
(9.10)^{* * *}\end{array}$ & $\begin{array}{r}0.031 \\
(0.99)\end{array}$ & $\begin{array}{l}0.107 \\
(4.61)^{* * *}\end{array}$ \\
\hline Year Dummy 2001 & $\begin{array}{l}0.411 \\
(16.25) * * *\end{array}$ & $\begin{array}{l}0.235 \\
(11.24)^{* * *}\end{array}$ & $\begin{array}{c}0.225 \\
(12.05)^{* * *}\end{array}$ & $\begin{array}{c}0.069 \\
(2.09)^{* *}\end{array}$ & $\begin{array}{l}0.151 \\
(6.12)^{* * *}\end{array}$ \\
\hline Year Dummy 2002 & $\begin{array}{l}0.468 \\
(21.37)^{* * *}\end{array}$ & $\begin{array}{l}0.314 \\
(13.19)^{* * *}\end{array}$ & $\begin{array}{l}0.302 \\
(14.07)^{* * *}\end{array}$ & $\begin{array}{l}0.127 \\
(3.62)^{* * *}\end{array}$ & $\begin{array}{l}0.212 \\
(8.18)^{* * *}\end{array}$ \\
\hline Log(Total Sales) t-1 & $\begin{array}{l}0.244 \\
(38.61)^{* * *}\end{array}$ & $\begin{array}{l}0.097 \\
(7.50)^{* * *}\end{array}$ & $\begin{array}{c}0.134 \\
(12.13)^{* * *}\end{array}$ & $\begin{array}{l}0.091 \\
(4.81)^{* * *}\end{array}$ & $\begin{array}{l}0.099 \\
(4.23)^{* * *}\end{array}$ \\
\hline $\begin{array}{l}\text { Sector-relative Shareholder } \\
\text { Returns }_{\mathrm{t}}\end{array}$ & $\begin{array}{l}0.002 \\
(0.22)\end{array}$ & & & & \\
\hline $\operatorname{Ln}(\text { Staff earning }>£ 50 \mathrm{k})_{\mathrm{t}}$ & & & & $\begin{array}{l}0.047 \\
(5.86)^{* * *}\end{array}$ & $\begin{array}{l}0.023 \\
(3.70)^{* * *}\end{array}$ \\
\hline Ln (PG Students) ${ }_{t-1}$ & & & & $\begin{array}{l}-0.018 \\
(1.38)\end{array}$ & $\begin{array}{r}0.005 \\
(0.32)\end{array}$ \\
\hline Ln $(\text { Research income })_{t-1}$ & & & & $\begin{array}{l}-0.006 \\
(1.06)\end{array}$ & $\begin{array}{l}-0.005 \\
(0.91)\end{array}$ \\
\hline Ln(non-UK/EU students $)_{\mathrm{t}-1}$ & & & & $\begin{array}{l}-0.009 \\
(1.29)\end{array}$ & $\begin{array}{l}-0.013 \\
(1.99)^{* *}\end{array}$ \\
\hline Log(Total FTE Students $)_{t-1}$ & & & & $\begin{array}{l}0.016 \\
(1.46)\end{array}$ & $\begin{array}{l}0.006 \\
(0.59)\end{array}$ \\
\hline $\begin{array}{l}\text { Wald Test for New } \\
\text { Variables (d.o.f.) }\end{array}$ & & & & $\begin{array}{l}22.00 * * * \\
(5)\end{array}$ & \\
\hline Adjusted $\mathrm{R}^{2}$ & $33.5 \%$ & $38.8 \%$ & $47.8 \%$ & $50.5 \%$ & $50.5 \%$ \\
\hline $\begin{array}{l}\text { Equation F-Ratio } \\
\text { (d.o.f.) }\end{array}$ & $\begin{array}{l}235.11 * * * \\
(7,3246)\end{array}$ & $\begin{array}{l}67.85 * * * \\
(6,634)\end{array}$ & $\begin{array}{l}81.57 * * * \\
(6,616)\end{array}$ & $\begin{array}{l}58.45 * * * \\
(11,611)\end{array}$ & $\begin{array}{l}58.45 * * * \\
(11,611)\end{array}$ \\
\hline Number of Observations & 3254 & 641 & 623 & 623 & 623 \\
\hline
\end{tabular}

Notes:

With the exception of the Random Effects Model, White's (1980) heterskedastic adjusted t-values (shown in parenthesis) have been used.

Significance levels $* \leq 0.10 ; * * \leq 0.05 * * * \leq 0.01$

The Datastream model was estimated using all UK listed non-financial firms with annual turnover between $£ 20$ million and $£ 1$ billion. 


\section{TABLE 4}

ESTIMATION OF UK UNIVERSITY VC PAY CHANGES: 1997 TO 2002

Dependent Variable $=\operatorname{Ln}(\mathrm{W})_{\mathrm{t}+1}-\mathrm{Ln}(\mathrm{W})_{\mathrm{t}}$

\begin{tabular}{|c|c|c|c|c|c|}
\hline Independent Variable & Model 2 & Model 3 & Model 4 & Model 5 & Model 5a \\
\hline Constant & $\begin{array}{l}0.065^{* * *} \\
(12.35)\end{array}$ & $\begin{array}{l}0.061^{* * *} \\
(9.31)\end{array}$ & $\begin{array}{l}0.067^{* * *} \\
(10.14)\end{array}$ & $\begin{array}{l}0.045 \\
(1.33)\end{array}$ & \\
\hline Change in VC Dummyt & $\begin{array}{l}-0.055^{* * *} \\
(2.59)\end{array}$ & $\begin{array}{l}-0.047 * * * \\
(3.38)\end{array}$ & $\begin{array}{l}-0.048^{* * * *} \\
(3.34)\end{array}$ & $\begin{array}{l}-0.047 * * * \\
(3.35)\end{array}$ & $\begin{array}{l}-0.046^{* * * *} \\
(3.33)\end{array}$ \\
\hline $\operatorname{Ln} \Delta(\text { Total Sales })_{\mathrm{t}}$ & $\begin{array}{r}-0.069 \\
(1.11)\end{array}$ & $\begin{array}{r}-0.028 \\
(0.46)\end{array}$ & $\begin{array}{r}-0.014 \\
(0.22)\end{array}$ & $\begin{array}{r}-0.025 \\
(0.41)\end{array}$ & \\
\hline $\operatorname{Ln} \Delta(\operatorname{Staff}>£ 50 \mathrm{k})_{\mathrm{t}}$ & $\begin{array}{l}0.015 * * * \\
(4.05)\end{array}$ & $\begin{array}{l}0.017 * * * \\
(4.89)\end{array}$ & $\begin{array}{l}0.012 * * * \\
(3.52)\end{array}$ & $\begin{array}{l}0.016^{* * *} \\
(4.26)\end{array}$ & $\begin{array}{l}0.015 * * * \\
(4.45)\end{array}$ \\
\hline $\operatorname{Ln} \Delta(\text { Total Students })_{t}$ & $\begin{array}{l}-0.008 \\
(0.25)\end{array}$ & $\begin{array}{l}-0.002 \\
(0.08)\end{array}$ & $\begin{array}{l}-0.006 \\
(0.22)\end{array}$ & $\begin{array}{l}-0.002 \\
(0.09)\end{array}$ & \\
\hline $\operatorname{Ln} \Delta(\text { Post-Grad Students })_{t}$ & $\begin{array}{r}0.010 \\
(0.36)\end{array}$ & $\begin{array}{r}0.005 \\
(0.24)\end{array}$ & $\begin{array}{l}-0.003 \\
(0.15)\end{array}$ & $\begin{array}{r}0.004 \\
(0.19)\end{array}$ & \\
\hline $\operatorname{Ln} \Delta(\text { non-UK/EU students })_{\mathrm{t}}$ & $\begin{array}{l}-0.004 \\
(0.27)\end{array}$ & $\begin{array}{l}-0.001 \\
(0.08)\end{array}$ & $\begin{array}{l}-0.004 \\
(0.29)\end{array}$ & $\begin{array}{l}-0.000 \\
(0.03)\end{array}$ & \\
\hline $\operatorname{Ln} \Delta(\text { Research income })_{\mathrm{t}}$ & $\begin{array}{l}-0.003 \\
(0.48)\end{array}$ & $\begin{array}{r}0.002 \\
(0.34)\end{array}$ & $\begin{array}{l}-0.001 \\
(0.20)\end{array}$ & $\begin{array}{r}0.002 \\
(0.32)\end{array}$ & \\
\hline$\left(\mathrm{LnW}^{\mathrm{VC}}{ }_{\mathrm{it}}-\mathrm{LnW}_{\mathrm{it}}\right)$ & & $\begin{array}{l}0.241^{* * *} \\
(4.46)\end{array}$ & & $\begin{array}{l}0.233^{* * *} \\
(7.55)\end{array}$ & $\begin{array}{l}0.233^{* * *} \\
(7.46)\end{array}$ \\
\hline$\left(\mathrm{LnW}^{\mathrm{VC}}{ }_{i t}-\mathrm{LnW}_{\mathrm{it}}\right)>0$ & & $\begin{array}{l}-0.015 \\
(0.17)\end{array}$ & & & \\
\hline$\left(\mathrm{LnW}^{\mathrm{CEO}}{ }_{\mathrm{it}}-\mathrm{LnW}_{\mathrm{it}}\right)$ & & & $\begin{array}{l}0.155^{* * *} \\
(6.50)\end{array}$ & & \\
\hline$\left(\mathrm{LnW}^{\mathrm{CEO}}{ }_{\text {it }}-\mathrm{LnW}^{\mathrm{VC}_{i t}}\right)$ & & & & $\begin{array}{r}0.017 \\
(0.46)\end{array}$ & $\begin{array}{l}0.065^{* * *} \\
(16.43)\end{array}$ \\
\hline Adjusted $\mathrm{R}^{2}$ & $8.3 \%$ & $19.4 \%$ & $16.1 \%$ & $19.4 \%$ & $19.4 \%$ \\
\hline $\begin{array}{l}\text { Equation F-Ratio } \\
\text { (d.o.f.) }\end{array}$ & $\begin{array}{l}9.06^{* * *} \\
(7,615)\end{array}$ & $\begin{array}{l}17.64 * * * \\
(9,613)\end{array}$ & $\begin{array}{l}15.90^{* * *} \\
(8,614)\end{array}$ & $\begin{array}{l}17.68^{* * *} \\
(9,613)\end{array}$ & $\begin{array}{l}52.61 * * * \\
(3,619)\end{array}$ \\
\hline $\begin{array}{l}\text { Wald Test for } \\
\text { additional/removed Variables } \\
\text { (d.o.f.) }\end{array}$ & & $\begin{array}{l}10.06^{* * *} \\
(2)\end{array}$ & $\begin{array}{l}11.92 * * * \\
(1)\end{array}$ & $\begin{array}{l}10.76^{* * *} \\
(2)\end{array}$ & $\begin{array}{l}2.21 \\
(6)\end{array}$ \\
\hline Number of Observations & 623 & 623 & 623 & 623 & 623 \\
\hline
\end{tabular}

Notes: White's (1980) heterskedastic adjusted t-values (shown in parenthesis) used.

significance levels $* \leq 0.10 ; * * \leq 0.05 * * * \leq 0.01$

With the exception of Model $5 \mathrm{a}$, where it refers to the number of variables removed relative to Model 5 , the Wald Test is a $\chi^{2}$ statistic with $\mathrm{k}$ d.o.f., where $\mathrm{k}=$ number of new variables relative to Model 2. 
TABLE 5

ESTIMATION OF VC PAY CHANGES BY TYPE OF UNIVERSITY

Dependent Variable $=\mathrm{Ln}(\mathrm{W})_{\mathrm{t}+1}-\mathrm{Ln}(\mathrm{W})_{\mathrm{t}}$

\begin{tabular}{|c|c|c|c|c|c|c|}
\hline $\begin{array}{l}\text { Independent Variable } \\
\text { Constant }\end{array}$ & $\begin{array}{c}\text { Model } 5 \\
\text { Pre-1992 } \\
0.057 \\
(1.22)\end{array}$ & $\begin{array}{c}\text { Model } 5 \\
\text { Post-1992 } \\
0.024 \\
(0.58)\end{array}$ & $\begin{array}{c}\text { Coefficient } \\
\text { Differences } \\
0.033 \\
(0.53)\end{array}$ & $\begin{array}{l}\text { Model 5a } \\
\text { Pre-1992 }\end{array}$ & $\begin{array}{l}\text { Model 5a } \\
\text { Post-1992 }\end{array}$ & $\begin{array}{l}\text { Coefficient } \\
\text { Differences }\end{array}$ \\
\hline Change in VC Dummy ${ }_{t}$ & $\begin{array}{l}-0.042 * * \\
(2.33)\end{array}$ & $\begin{array}{l}-0.060 * * * \\
(2.73)\end{array}$ & $\begin{array}{r}0.018 \\
(0.53)\end{array}$ & $\begin{array}{l}-0.042 * * \\
(2.40)\end{array}$ & $\begin{array}{l}-0.056^{* * *} \\
(2.50)\end{array}$ & $\begin{array}{r}0.015 \\
(0.51)\end{array}$ \\
\hline $\operatorname{Ln} \Delta$ (Total Sales $)_{t}$ & $\begin{array}{r}-0.048 \\
(0.69)\end{array}$ & $\begin{array}{l}0.027 \\
(0.25)\end{array}$ & $\begin{array}{r}-0.075 \\
(0.59)\end{array}$ & & & \\
\hline $\operatorname{Ln} \Delta(\operatorname{Staff}>£ 50 \mathrm{k})_{\mathrm{t}}$ & $\begin{array}{l}0.019 * * * \\
(4.04)\end{array}$ & $\begin{array}{l}0.009 \\
(1.37)\end{array}$ & $\begin{array}{l}0.010 \\
(1.31)\end{array}$ & $\begin{array}{l}0.017 * * * \\
(4.39)\end{array}$ & $\begin{array}{l}0.007 \\
(1.13)\end{array}$ & $\begin{array}{l}0.010 \\
(1.42)\end{array}$ \\
\hline $\operatorname{Ln} \Delta(\text { Total Students })_{\mathrm{t}}$ & $\begin{array}{l}-0.041 \\
(0.92)\end{array}$ & $\begin{array}{l}0.091^{* * * *} \\
(2.48)\end{array}$ & $\begin{array}{l}-0.131 * * \\
(2.29)\end{array}$ & & & \\
\hline $\operatorname{Ln} \Delta(\text { Post-Grad Students })_{\mathrm{t}}$ & $\begin{array}{l}0.056^{*} \\
(1.83)\end{array}$ & $\begin{array}{l}-0.089 * * * \\
(2.99)\end{array}$ & $\begin{array}{l}0.145^{* * *} \\
(3.40)\end{array}$ & & & \\
\hline $\mathrm{Ln} \Delta(\text { non-UK/EU students })_{\mathrm{t}}$ & $\begin{array}{l}-0.007 \\
(0.36)\end{array}$ & $\begin{array}{l}-0.015 \\
(0.62)\end{array}$ & $\begin{array}{r}0.008 \\
(0.27)\end{array}$ & & & \\
\hline $\operatorname{Ln} \Delta(\text { Research income })_{\mathrm{t}}$ & $\begin{array}{l}0.026^{* *} \\
(1.95)\end{array}$ & $\begin{array}{l}-0.005 \\
(1.06)\end{array}$ & $\begin{array}{l}0.032 * * \\
(2.20)\end{array}$ & & & \\
\hline$\left(\mathrm{LnW}^{\mathrm{VC}}{ }_{\text {it }}-\mathrm{LnW}_{\mathrm{it}}\right)$ & $\begin{array}{l}0.224^{* * *} \\
(6.06)\end{array}$ & $\begin{array}{l}0.255^{* * *} \\
(5.30)\end{array}$ & $\begin{array}{l}-0.031 \\
(0.51)\end{array}$ & $\begin{array}{l}0.221 * * * \\
(5.68)\end{array}$ & $\begin{array}{l}0.258 * * * \\
(5.17)\end{array}$ & $\begin{array}{l}-0.037 \\
(0.59)\end{array}$ \\
\hline$\left(\mathrm{LnW}^{\mathrm{CEO}}{ }_{i t}-\mathrm{LnW}^{\mathrm{VC}}{ }_{i t}\right)$ & $\begin{array}{r}0.002 \\
(0.03)\end{array}$ & $\begin{array}{r}0.047 \\
(1.02)\end{array}$ & $\begin{array}{l}-0.045 \\
(0.64)\end{array}$ & $\begin{array}{l}0.065 * * * \\
(13.11)\end{array}$ & $\begin{array}{l}0.069 * * * \\
(9.96)\end{array}$ & $\begin{array}{l}-0.004 \\
(0.47)\end{array}$ \\
\hline Adjusted $\mathrm{R}^{2}$ & $21.5 \%$ & $18.6 \%$ & $20.6 \%$ & $21.0 \%$ & $17.4 \%$ & $19.9 \%$ \\
\hline $\begin{array}{l}\text { Equation F-Ratio } \\
\text { (d.o.f.) }\end{array}$ & $\begin{array}{l}12.18 * * * \\
(9,359)\end{array}$ & $\begin{array}{l}7.43 * * * \\
(9,244)\end{array}$ & $\begin{array}{l}9.48 * * * \\
(19,603)\end{array}$ & $\begin{array}{l}33.69 * * * \\
(3,365)\end{array}$ & $\begin{array}{l}18.75 * * * \\
(3,250)\end{array}$ & $\begin{array}{l}23.08 * * * \\
(7,615)\end{array}$ \\
\hline $\begin{array}{l}\text { Wald Test for } \\
\text { additional/removed Variables } \\
\text { (d.o.f.) }\end{array}$ & & & $\begin{array}{l}18.73^{* * *} \\
(10)\end{array}$ & $\begin{array}{c}8.23 \\
(6)\end{array}$ & $\begin{array}{l}9.77 \\
(6)\end{array}$ & $\begin{array}{l}3.73 \\
(4)\end{array}$ \\
\hline $\begin{array}{r}\text { Number of Observations } \\
\text { Notes: White's (1980) } \\
\text { significance lev } \\
\text { The Wald Test } \\
\text { interaction tern } \\
\text { The Wald Test } \\
\text { of the k variabl }\end{array}$ & $\begin{array}{l}\quad 369 \\
\text { rskedastic ac } \\
* \leq 0.10 ; * * \\
\text { stics in the c } \\
\text { dded to the T } \\
\text { stics in the } \\
\text { emoved rela }\end{array}$ & $\begin{array}{l}254 \\
\text { ed } \mathrm{t} \text {-values } \\
05 * * * \leq \\
\text { icient differ } \\
4 \text { estimates } \\
\text { and post } 199 \\
\text { to Model } 5\end{array}$ & $\begin{array}{l}\quad 623 \\
\text { own in parent } \\
0 \text {. } \\
\text { es columns re } \\
\text { models } 5 \text { anc } \\
\text { Model } 5 \mathrm{a} \text { colu } \\
\text { he current tab }\end{array}$ & $\begin{array}{l}\quad 369 \\
\text { is) used. } \\
\text { to the statist } \\
\text { a. } \\
\text { s refer to the }\end{array}$ & 1 significan & the $\mathrm{k}$ \\
\hline
\end{tabular}




\section{Figure One \\ Reactions in the Times Higher Educational Supplement (THES) to the publication of Vice Chancellors Pay Awards}

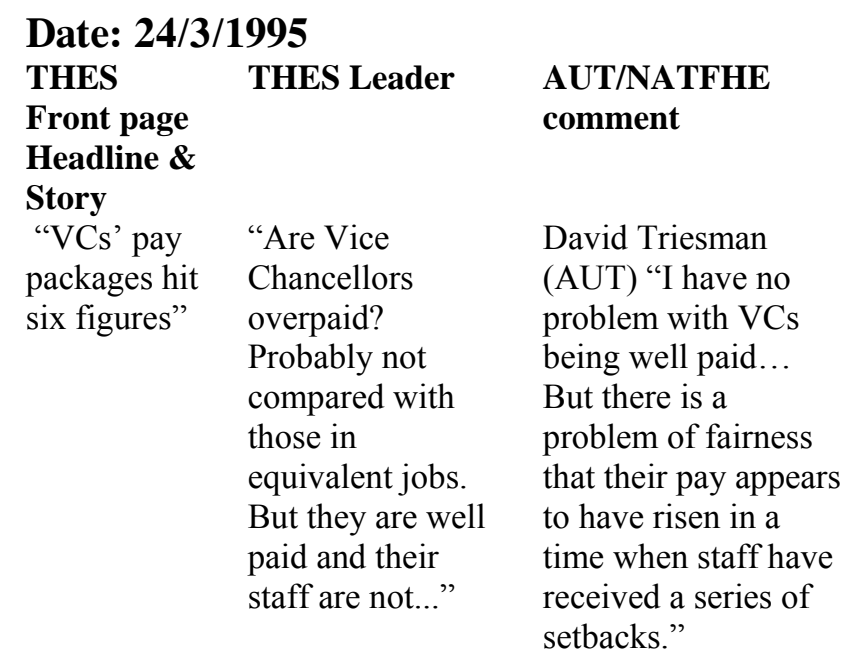

\author{
CVCP/UUK/VC \\ comment
}

Derek Roberts (UCL), the highest paid $\mathrm{VC}$ : "the only issue for me is whether the people who fix my pay think I am worth it. Previously a director of GEC, he said his pay had fallen by a factor of 3 when he moved to UCL. Mike Fitzgerald (TVU), the lowest paid VC (£68k) "I am the highest paid person in this institution and I think I am very well paid for what I do."

\section{Other comments}

Gavin MacKenzie (headhunter): "I have a sense that the trend is upwards... The figures remain lower than comparable private sector rewards."

\section{Date: 9/2/1996 No THES Leader, AUT/NATFHE or Other Comments THES Front page CVCP/UUK/VC comment}

Headline \& Story "Who gets paid

George Bain (LBS) explaining that the high average pay for LBS faculty has succeeded in attracting international stars most"

\section{Date: 7/2/1997 No Other Comments}

\section{THES}

\section{THES Leader}

Front page

Headline \&

Story

"More VCs "A labour government is get six likely to make sharp pay appeal."

\section{hikes for top people} unfashionable. While this will reduce envy. It will not release much money. The uncomfortable message for universities is the one from LBS. Substantially higher pay all round will be forthcoming only where the institution has substantial private sources of revenue. It will not be provided by this or any other government."

\section{AUT/NATFHE comment}

David Triesman (AUT)

"Medium pay rises for vice chancellors in what they tell us is a dreadful year are twice what they awarded their staff. These rises have been approved by university remuneration committees using comparability data, just like pay review. I believed in the right pay and the right methodology for academic related jobs, but I do wonder why it took ten months to inch forward to our likely settlement"

\section{CVCP/UUK/VC comment}

Diana Warwick, chief executive of the CVCP: "Vice Chancellors' salaries are negotiated individually. They remain considerably below those for chief executives of other multimillion pounds corporations, public or private."

George Bain, principal of London Business School - third in the list with $£ 136,000$ said, "there are two or three people here who make more. These increases are a consequence of policies of competing internationally for the best staff, and performancerelated pay" 
Date: 6/2/1998 No THES Leader or CVCP/UUK/VC Comment THES Front AUT/NATFHE comment

page

Headline \&

Story

"Is your vice-

chancellor's

salary over-

inflated?"

Tom Wilson (NATFHE): "We are outraged at increases which are so flagrantly ahead of increases ordinary staff received over the last two years" He also commented that, as the vice-chancellors' pay was determined by local remuneration committees which took account of factors very similar to those considered by a pay review body, what is good for them, should therefore also be good for the vice-chancellor's staff

David Triesman (AUT): "the review body award for doctors and dentists, as much as the teachers' award, is now the benchmark, and that is what the member aspire to. The AUT also argue that doctors and dentists in university clinical department work alongside other higher education teacher and all deserve the same treatment. The AUT says that it is only fair that the pay for nonclinical staff involved in medical education should match that of their clinical colleagues.

\section{Date: 5/2/1999 No THES Leader}

\section{THES Front AUT/NATFHE comment}

page

Headline \&

Story

Unions envy

$4.8 \%$ rise

Plea to

double professors' pay

\section{CVCP/UUK/ VC comment}

Paul Cottrell (AUT) "As always there is no doubt that VC's deserve every penny but a university's achievements depend on all its staff as much as the individual at the top ... We don't begrudge VCs their pay increase but yet again they are paying themselves a far greater increase than they do their staff. We wait to hear of a VC who refuses to take a bigger pay rise than his staff. We suspect it will be a long wait."

THES comment: "Many new VC earned less than their predecessors. The most striking was Alexandra Burslem of Manchester Metropolitan University, who earned 27.3\% less than the previous incumbent, Sir Kenneth Green. Just three new VC earned more than their predecessors, including George Bain."
Sir Alec

Broers, Cambridge's $\mathrm{VC}$, said the university could not pay enough to attract researchers from industry or abroad.

"Americans just laugh at us," he said

\section{Other comments}

Baroness Blackstone, higher education minister told Natfhe "that it gives no promises about extra money for universities. She admitted that academics were underpaid, that universities faced a 'financial crisis' with not enough books in the libraries, not enough seats, underpaid academics, research staff on short contracts and a serious problem of maintaining the sort of studies in British universities that have made them internationally acclaimed for the past 50 years."

\section{Other comments}

University professors' salaries should be doubled, the house of commons science and technology committee was told this week.

"The increase that our VC has taken has always been greater than inflation and then his managers tell us that our expectations are unrealistic. The VC should show some solidarity with the staff that he professes to admire. What does it do to the morale of staff when they see their VC being awarded a big increase on an already large salary?"- Sandi Golbey of the University of Nottingham, where a $10.4 \%$ pay rise took the VC's salary to $£ 127,000$ 
Date: 28/2/2000 No THES Leader or CVCP/UUK/VC Comment

\section{THES \\ Front page}

Headline \&

\section{Story}

Uni boss's

pay tops

$£ 250,000$
AUT/NATFHE comment

Malcolm Keight (AUT): "Vice-Chancellors obviously recognise how important pay is for motivation. We look forward to the vice-chancellors responding to our latest pay claim, so they can show the same applies to the rest of staff as it does to themselves."

"If VC's had offered a $4.9 \%$ deal to their staff, it would at least have shown a willingness to address higher education's problems. The success of higher education is due to all its people and not just its chiefs," said an AUT Spokeswoman
Other comments

"staff in HE remain very despondent about our pay and conditions. To see VC's receive a pay reward far ahead of ours on a salary that is already much greater than ours adds that despondency. It is not the amount that he is paid out but the disparity between the $\mathrm{VC}$ 's pay and other staff... Gargi Bhattacharyya of the University of Birmingham, where VC Maxwell Irvine's $10.6 \%$ pay took his salary to $£ 136000$."

\section{Date: 26/1/2001 No THES Leader or CVCP/UUK/VC Comment THES Front AUT/NATFHE comment \\ Other comments \\ page \\ Headline \&}

Story

Union fury at

David Triesman (AUT): "It is shameless that vice-

"shameless"

chancellors can consider paying themselves that on the backs

of the people who do the work and on whom they have imposed a 3\% pay rise".... Despite the rises, vicechancellors' salaries remain modest compared with senior figures in the private sector...

\section{Date: 8/2/2002 No CVCP/UUK/VC or Other comments \\ THES Front page Headline THES Leader} \& Story Union fury as VC pay hits $£ 309 \mathrm{k}$
The amounts vice-chancellors are now being paid its outrageous - and most offensive of all is the practice of bumping up salaries in the year before retirement, thereby sticking a large bill on the Universities Superannuation Scheme, one of the endangered breed of final-salary pension schemes. High pay and perks might be justified if vicechancellors were responsible for the success or failure of major enterprises. But they are not. Thanks to their and their predecessors' pusillanimity, they in fact preside over what are, in effect, branch offices of a nationalised industry.

\section{AUT/NATFHE comment}

Tom Wilson (NATFHE): "It is extraordinary that vice-chancellors feel comfortable taking three times what they offer their staff. If remuneration committees are carefully judging them, what are their criteria? Retention is not good. The number of institutions forecasting a deficit has doubled Overseas recruitment is below target." 
Date: 7/2/2003 No THES Leader or CVCP/UUK/VC comment

THES AUT/NATFHE comment

Other comments

Front page

Headline

\& Story

Union fury

Sally Hunt (AUT): "The fact that the average pay

as VCs rise for a vice-chancellor was $6.1 \%$ is

astonishing, particularly when you think that they

pocket $6 \%$ keep saying that they don't have enough money to

pay rise pay their staff a decent, competitive wage. Many university employees are sick of seeing vicechancellors' pay shoot into the stratosphere while theirs remains more or less rooted to the spot. If there's enough money to give vice-chancellors exorbitant pay packages, there should be enough to pay rank and file staff an acceptable wage."

Tom Wilson (Natfhe): "It beggars belief that vice-chancellors' pay should rise by almost double the $3.5 \%$ awarded to their staff. We call on the Higher Education Funding Council for England to halt this slide to greed and ensure that the same modern standards of fairness and transparency apply to vice-chancellors' pay as to pay of all other staff."

Andrew Oswald, professor of economics at Warwick University commented that,

“... it is plain that vice-chancellors are underpaid, not over paid. It is bad for any of us and inherently childish to dwell obsessively on the lives of others. In other aspects of university life, there is general criticism (deserved, I think) of league tables and rankings. Yet many university teachers seem to forget this when it comes to league tables of their bosses' remuneration. Suddenly, the critics become avid consumers.... vice-chancellors are chief executives of big complicated organisations. In the business world, such people now usually earn between $£ 500000$ and $£ 1$ million a year. Many dozens of them earn more than $£ 1$ million a year. By contrast, the typical vice-chancellor in our country takes home about $£ 150000$ a year... Salaries in universities have to be competitive with those paid outside academia... "

Notes: AUT $=$ Association of University Teachers (Union members predominantly in the pre 1992 Universities)

NATFHE $=$ National Association of Teachers in Further and Higher Education

$\mathrm{CVCP}=$ Conference of Vice Chancellors and Principals

$\mathrm{UUK}=$ Universities UK (the successor to the CVCP) 
${ }^{1}$ In the paper we use the term VC to refer to the executive head of the institution, even though in some cases the post had an alternative title such as Principal (e.g., the Scottish Universities) or Director (e.g., specialist colleges and institutes).

${ }^{2}$ It is worth stressing that none of the UK corporate governance reports (i.e., Cadbury, 1992; Greenbury, 1995; Hampel, 1998; Higgs, 2003) have suggested that remuneration committee ought to control or attempt to hold down executive pay.

${ }^{3}$ Even prior to their widespread introduction in 1993, it was apparent that firms with remuneration committees tended to award relatively generous pay increases to their CEOs and were largely reliant upon the information and recommendations supplied by outside "pay consultants" regarding "comparable" market pay rates and the complexities of performancerelated pay schemes (see Main and Johnson, 1993 and Forbes and Watson, 1993 for reviews of the evidence).

${ }^{4}$ Whilst the water company remuneration committees did award large percentage pay rises to their CEOs in the early post-privatisation period, because pre-privatisation pay levels were particularly low, even after these rises the average water company's CEO pay still remained much lower than that of CEOs running comparable sized UK firms.

${ }^{5}$ Regulatory price controls ensure that shareholders rather than customers bear the cost of executive pay increases.

${ }^{6}$ The University Council is the title used by the pre-1992 Universities. The governing body of the post-1992 institutions is generally known as the "board of governors".

${ }^{7}$ This model (Model 1, shown in Table 3) is discussed in the following section.

${ }^{8}$ The percentage increase in pay scale rates highlighted by the Association of University Teachers (AUT), is actually a significant underestimate of the typical increase in pay experienced by staff in post throughout the period. This is because, for staff not currently at the top of a scale, there is an automatic progression each year up the pay scale. Even for staff at the top of a scale there is the possibility of being awarded additional "discretionary" increments and/or being internally promoted to a higher grade.

${ }^{9}$ Though we produce some pay level estimates in Table 3, it is worth stressing that the focus of our analysis is the determinants of VC pay awards (changes). For the reasons stated in the text, we do not attempt to estimate a complete model of VC pay levels as has been attempted previously by Bainbridge and Simpson (1996) or Dolton and Ma (2003).

${ }^{10}$ As can be seen from the correlation matrix shown in Table 2, the various University characteristics are all highly correlated. However, the first-differences, i.e., changes, of these variables are, as can be seen from section B of Table 2, very much less highly correlated with each other.

${ }^{11}$ We also estimated all of the models excluding cases where there had been a change in VC. The results were statistically indistinguishable from the results presented in the paper. 